\title{
DOCTRINA DEL TRIBUNAL CONSTITUCIONAL DURANTE EL TERCER CUATRIMESTRE DE 2018
}

Doctrine of the Constitutional Court during the third four-month period of 2018

\author{
JUAN CARLOS DUQUE VILLANUEVA \\ Tribunal Constitucional \\ duque@tribunalconstitucional.es \\ CARLOS ORTEGA CARBALLO \\ Tribunal de Cuentas \\ carlos.ortega@tcu.es \\ HERMINIO LOSADA GONZÁLEZ \\ Tribunal Constitucional \\ losada@tribunalconstitucional.es

\section{TOMÁS DE LA QUADRA-SALCEDO JANINI \\ Tribunal Constitucional \\ Tomas.quadra@uam.es}


I. JURISDICCIÓN CONSTITUCIONAL. DERECHO PROCESAL CONSTITUCIONAL. II. FUENTES DEL DERECHO. III. ESTRUCTURA TERRITORIAL DEL ESTADO. IV. ORGANIZACIÓN DE LOS PODERES PÚBLICOS. V. DERECHOS FUNDAMENTALES.

\section{JURISDICCIÓN CONSTITUCIONAL. DERECHO PROCESAL CONSTITUCIONAL}

1. Las resoluciones dictadas por el TC durante este cuatrimestre en las que se abordan cuestiones de naturaleza procesal han sido más numerosas que en los últimos cuatrimestres y sus pronunciamientos, de los que a continuación se deja constancia, no han estado exentos de algunas novedades.

En relación con los recursos de inconstitucionalidad, las SSTC $97^{1} \mathrm{y}$ 99/12018² (Pleno), de 19 de septiembre, tratan, respectivamente, sobre la legitimación del Gobierno en funciones y del Defensor del Pueblo para interponer un recurso de inconstitucionalidad.

Por lo que a la legitimación del Gobierno en funciones se refiere, el TC desestima el óbice procesal alegado por la parte demandada, ya que la Constitución no establece restricción alguna a su legitimación para promover recurso de inconstitucionalidad y menciona los precedentes en los que ha sido admitida (FJ 2).

Asimismo, el TC recuerda que la legitimación del Defensor del Pueblo para interponer un recurso de inconstitucionalidad no se encuentra constreñida, en razón de la función constitucionalmente encomendada (art. $54 \mathrm{CE}$ ), a la defensa de los derechos y libertades del título I CE, sino que, como ya ha tenido ocasión de declarar en anteriores pronunciamientos, su legitimación ha de entenderse en los mismos términos y con la misma amplitud que el resto de los sujetos contemplados en los arts. 162.1. a) CE y 32.1 LOTC, pues «dicha legitimación les ha sido reconocida a cada uno de ellos no en atención a su interés, sino en virtud de la alta cualificación política que se infiere de su respectivo cometido constitucional». A lo que añade que ni la Constitución ni los preceptos de la ley orgánica reguladora de la institución establecen límite

\footnotetext{
1 Véanse infra pp. 272-275.

2 Véanse infra pp. 267-268.
} 
alguno al contenido de su legitimación para interponer recurso de inconstitucionalidad (FJ 3).

2. En la STC 124/2018 (Pleno), de 14 de noviembre ${ }^{3}$, que resuelve el conflicto entre órganos constitucionales promovido por el Congreso de los Diputados contra el Gobierno respecto al sometimiento de este al encontrarse en funciones al control político de la Cámara, el TC aborda diversos óbices procesales planteados por el abogado del Estado, así como la pervivencia del proceso constitucional por haber concluido la legislatura en el momento de su resolución.

a) El abogado del Estado suscita en primer lugar la posible falta de legitimación de la Mesa de la Diputación Permanente para poder plantear el conflicto, ya que considera que resultan necesarios dos acuerdos del Pleno de la Cámara o de su Diputación Permanente, uno relativo al requerimiento de asunción o invasión de atribuciones ajenas y el otro referido al planteamiento del conflicto, que exige una valoración de la respuesta recibida a aquel requerimiento.

El TC, tras reiterar el criterio, ya sentado en relación con otros procesos constitucionales, de que la decisión de admisión de un conflicto de atribuciones ha de regirse exclusivamente por lo dispuesto en su LOTC, desestima el óbice procesal del abogado del Estado. A su juicio, el tenor del art. 73 LOTC «no requiere expresamente dos acuerdos del Pleno del órgano constitucional para el planteamiento del conflicto de atribuciones», siendo una actividad distinta el requerimiento «al planteamiento y formalización del conflicto», sin que respecto a estas últimas actividades el art. 73.2 LOTC exija "un segundo acuerdo del Pleno, sino únicamente que el órgano requerido afirme que actúa en el ejercicio constitucional y legal de sus atribuciones o el transcurso de un plazo sin rectificar».

Aunque, obviamente, no se puede hurtar al Pleno del órgano promotor del conflicto el debate o la valoración de la contestación del órgano requerido, el TC entiende que si este se limita a afirmar que ha actuado en el ejercicio constitucional y legal de sus atribuciones o no rectifica en el sentido que se le ha solicitado en el plazo legalmente establecido «no será necesario otro acuerdo del Pleno [del órgano promotor] puesto que el propio precepto [art. 73.2 LOTC] permite el planteamiento del conflicto".

En definitiva, el TC considera que habiendo acordado el Pleno del Congreso de los Diputados la formulación de requerimiento al Gobierno y contestado este en el sentido de afirmar que estaba actuando en el ejercicio de

$3 \quad$ Véanse infra pp. 286-287. 
sus atribuciones, sin que la Diputación Permanente haya recabado una nueva valoración de la contestación del Gobierno, la Mesa de la Diputación Permanente se ha limitado a la ejecución del acuerdo adoptado por el Pleno de la Cámara, por lo que la existencia o inexistencia de un segundo acuerdo de la Diputación Permanente no vicia el planteamiento del conflicto constitucional (FJ 2, A.a).

b) El TC también desestima la indeterminación del objeto del proceso constitucional denunciada por el abogado del Estado, para quien en la demanda no se concretaban las decisiones o actos impugnados.

Tras constatar que la demanda se ajusta a los requisitos que establece el art. 73.2 LOTC y que la reivindicación competencial -el control parlamentario del Gobierno en funciones - está claramente expresada en el suplico, el TC identifica como decisiones recurridas los escritos remitidos por el Ministerio de la Presidencia a la Cámara en los que se rechaza el requerimiento de revocar el criterio del Gobierno en funciones de no someterse al control de la Cámara en la medida en que no existe una relación de confianza entre aquel y esta. Por lo que respeta a la amplitud de la pretensión contenida en el suplico de la demanda, estima que es de igual magnitud que la formulación del criterio del Gobierno que da origen al conflicto de atribuciones de no someterse a iniciativas de control de la Cámara (FJ 2 A.b).

c) Y, en fin, se afirma en la sentencia que la finalización de la legislatura en la que se ha promovido el conflicto entre órganos constitucionales no afecta a la pervivencia del proceso, sin perjuicio de la incidencia que puede tener, como efectivamente ha tenido, en el alcance del pronunciamiento que resuelva la controversia (FJ $3 \mathrm{C})$.

3. La posibilidad de plantear en un proceso de impugnación de disposiciones autonómicas del título V LOTC como motivo de inconstitucionalidad y nulidad de los preceptos recurridos el incumplimiento de una sentencia o resolución del TC ha sido descartada en la STC 136/2018 (Pleno), de 13 de diciembre. Tal pretensión no se puede sustanciar por este proceso constitucional, sino que ha de encauzarse a través del incidente de ejecución del art. 92 LOTC, dadas las sustanciales diferencias que existen entre aquel proceso y este incidente.

Diferencias de las que se resaltan las siguientes: i) los trámites y requisitos procesales de los incidentes de ejecución son diferentes a los del proceso de impugnación de disposiciones autonómicas, pues los sujetos legitimados para promover uno y otro son diferentes en cada caso, así como preceptiva en un supuesto y no en el otro la presencia del Ministerio Fiscal; ii) en el proceso de impugnación de disposiciones autonómicas se puede declarar la inconstitucionalidad y nulidad 
de la disposición o resolución impugnada, lo que no puede hacerse en un incidente de ejecución, cuyos posibles pronunciamientos son diferentes y más amplios; $y$, en fin, iii) el control que el TC lleva a cabo en el proceso de impugnación de disposiciones autonómicas es eminentemente objetivo, al margen de las intenciones o finalidad del autor de la disposición o norma recurrida, en tanto que en el incidente la existencia de un incumplimiento de lo resuelto por el TC exige indagar en la voluntad del poder público autor de la resolución impugnada.

Así pues, no puede canalizarse a través del proceso de impugnación de disposiciones autonómicas una pretensión de incumplimiento de una sentencia o resolución del TC, sin perjuicio de la facultad de este de velar, en los términos del art. 92 LOTC, por el incumplimiento efectivo de sus resoluciones $(\mathrm{FJ} 4)$.

4. Los motivos de especial trascendencia constitucional apreciados en los recursos de amparo resueltos durante este cuatrimestre han sido los siguientes: 1) (STC 155/2009, FJ 2 a) que el recurso plantea un problema o afecta a la faceta de un derecho fundamental sobre el que no ha doctrina del TC (SSTC $91^{4}$ y 92/2018 [Sala Primera], de 17 de septiembre — prisión provisional tras condena en primera instancia de quien está en libertad sin la celebración de la comparecencia del art. 505 LECrim—; 93/2018 [Sala Segunda], de 17 de septiembre ${ }^{5}$-notificación edictal de incoación de expediente sancionador y de la resolución final—; 94/2018 [Sala Segunda], de 17 de septiembre ${ }^{6}$, y 139/2018 [Sala Primera], de 17 de diciembre ${ }^{7}$ — no sometimiento a la toma en consideración de una proposición de ley por el veto presupuestario del Gobierno-; 95/2018 [Sala Primera], de 17 de septiembre, y 123/2018 [Sala Primera], de 12 de noviembre ${ }^{8}$ - desconocimiento de la garantía de la prioridad de permanencia en la empresa otorgada por convenio colectivo a representante de los trabajadores-; 108 y 109/2018 [Sala Primera], de 15 de octubre, 114, 115 y 116/2018 [Sala Primera], de 29 de octubre, 118/2018 [Sala Segunda], de 29 de octubre, 126/2018 [Sala Primera], de 26 de noviembre, y 127/2018 [Sala Segunda], de 26 de noviembre — despido de trabajador

\footnotetext{
Véanse infra pp. 289-291.

Véase infra pp. 296-297.

6 También se apreció como motivo de especial trascendencia constitucional que el asunto suscitado trasciende del caso concreto porque pudiera tener unas consecuencias jurídicas generales (STC 155/2009, FJ 2 g). Véanse también infra pp. 285 y 293-295.

7 Véase también infra p. 285-286.

8 Véanse infra pp. 300-301.
} 
miembro del comité de empresa por exhibir lemas críticos con la empresa y participar en el anuncio de una convocatoria de huelga—; 125/2018 [Sala Segunda], de 26 de noviembre ${ }^{9}$ — despido por absentismo al no computarse como horas trabajadas las horas de asistencia a los plenos de la corporación local de la que es miembro la demandante-; 129, 130 y 131/2018 [Pleno], de 12 de diciembre ${ }^{10}$ — competencia de un órgano jurisdiccional para la instrucción y enjuiciamiento de una causa penal—; 133/2018 [Pleno], de 13 de diciembre - actuación de una comisión parlamentaria de investigación que no preserva el derecho del investigado a no ser considerado y tratado como no autor o partícipe en conductas ilícitas-, y ATC 119/2018 [Pleno], de 13 de noviembre - ejecución de resolución judicial en proceso de selección del presidente de un Tribunal Superior de Justicia-); 2) (STC 155/2009, FJ 2 b) que el recurso pueda dar ocasión al TC para aclarar o cambiar su doctrina como consecuencia de un proceso de reflexión interna (STC 101/2018 [Sala Segunda], de 1 de octubre - sobreseimiento provisional y archivo de diligencias previas en causa por delito de prevaricación-, y STC 113/2018 [Sala Segunda], de 29 de octubre ${ }^{11}$ —resoluciones judiciales que sin oír a las partes acuerdan el cumplimiento parcial de la pena de prisión y la posterior expulsión del territorio nacional-), y 3) (STC 155/2009, FJ 2 b) que el recurso puede dar ocasión al TC para aclarar o cambiar su doctrina como consecuencia de cambios normativos en la configuración del derecho fundamental (SSTC 111/2018 [Pleno], de 17 de octubre ${ }^{12}$, 117/2018 [Sala Primera], de 29 de octubre, y 138/2018 [Sala Primera], de 17 de diciembre ${ }^{13}$ —equiparación en extensión temporal del permiso paternidad con el de maternidad-).

Por otra parte, durante este cuatrimestre no son pocas las sentencias en las que el TC no se limita a enunciar el motivo o los motivos de especial trascendencia constitucional apreciados, sino que además explica por qué concurren,

Véanse infra pp. 295-296.

10 En las SSTC 130 y 131/2018 también se apreció como motivo de especial trascendencia constitucional que el recurso puede dar ocasión al TC para aclarar o cambiar su doctrina como consecuencia de un proceso de reflexión interna (STC 155/2009, FJ 2 b).

11 Véanse infra pp. 297-298.

12 Véanse infra pp. 287-289.

13 También se apreciaron como motivos de especial trascendencia constitucional que la posible vulneración del derecho fundamental puede provenir de una ley o de una disposición de carácter general (STC 155/2009, FJ 2 e) y que el asunto suscitado trasciende el caso concreto porque plantea una cuestión jurídica relevante de general repercusión social o económica (STC 155/2009, FJ 2 g). 
precisando, por ejemplo, cuál es el problema o la faceta nueva que plantea el recurso y los aspectos novedosos que presenta respecto a precedentes pronunciamientos o sobre los que va a versar la aclaración o el cambio de doctrina (SSTC 91 y 92/2018 [Sala Primera], de 17 de septiembre, FF. JJ. 2; 93/2018 [Sala Segunda], de 17 de septiembre, FJ 2; 108/2018 [Sala Primera], de 15 de octubre, FJ 2, y STC 118/2018 [Pleno], de 17 de octubre, FJ 2, entre otras).

En relación con el cumplimiento del requisito de la justificación de la especial trascendencia constitucional, la STC 93/2018 (Sala Segunda), de 17 de septiembre $^{14}$, considera factible en un recurso de amparo del art. 43 LOTC, esto es, dirigido directamente contra actuaciones de las Administraciones públicas, disociar entre la vulneración del derecho fundamental, imputable en este caso a la actuación administrativa impugnada, y el motivo de especial trascendencia constitucional alegado, referido exclusivamente a las actuaciones jurisdiccionales como es el haber incurrido los órganos judiciales en una negativa manifiesta del deber de acatamiento a la doctrina del TC (STC 155/2009, FJ 2 f). Se afirma en la sentencia que esa discordancia entre la vulneración del derecho fundamental denunciada y el motivo de especial trascendencia constitucional invocado no es obstáculo para la admisibilidad del recurso de amparo, pues, dado su carácter subsidiario, el control de constitucionalidad del TC «no se constriñe necesariamente a una concreta actuación que se considere lesiva del derecho fundamental, sino que se proyecta sobre el funcionamiento en conjunto del sistema de protección de los derechos fundamentales». A lo que se añade que la diferente función de uno y otro requisito «abunda en la legitimidad de admitir la disociación entre la circunstancia causante de la lesión y la que dotaría al recurso de una especial trascendencia constitucional» (FJ 2).

Asimismo, por lo que al requisito de la justificación de la especial trascendencia constitucional se refiere, su insuficiencia es posible apreciarla en el trámite de sentencia, al igual que el resto de los requisitos procesales insubsanables de que pudiera estar afectado un recurso de amparo (STC 101/2018 [Sala Segunda], de 1 de octubre, FJ 3). El TC califica en esta resolución de insuficiente la justificación de la especial trascendencia constitucional porque el recurrente, habiendo invocado como motivos de especial trascendencia constitucional el incumplimiento general y reiterado de la doctrina constitucional por los órganos judiciales y la existencia de resoluciones judiciales contradictorias sobre los derechos fundamentales comprometidos en el proceso, en la demanda «no hay precisión alguna que materialice y concrete ese supuesto apartamiento de la doctrina o de la contradicción de resoluciones». Por el contrario, el recurrente hace una mención abstracta a la especial

$14 \quad$ Véase infra pp. 296-297. 
trascendencia constitucional por referencia a la gravedad de los hechos y los presuntos delitos cometidos, sin aportar el esfuerzo argumental exigible para asociar esa afirmación con el derecho a la prueba (ibid.).

En fin, el requisito de admisibilidad de la especial trascendencia constitucional se proyecta sobre toda la serie de recursos que planteen el mismo problema siempre que la sentencia recaída en el primer recurso sea de fecha posterior a las resoluciones judiciales impugnadas en los restantes (STC 139/2018 [Sala Primera], de 17 de diciembre, FJ 3). Este criterio parece, por lo tanto, que excluye la posibilidad de que el TC, en una serie de recursos de amparo que susciten la misma cuestión desde una perspectiva constitucional, pueda optar por admitir uno a trámite, por entender que la cuestión planteada reviste especial trascendencia constitucional, e inadmitir los demás, al considerar que la admisión y resolución de tan solo de uno de los recursos es suficiente para pronunciarse sobre el problema constitucional suscitado.

5. En relación con el recurso de amparo contra decisiones y actos parlamentarios sin valor de ley (art. 42 LOTC), el TC se ha pronunciado en la STC 133/2018 (Pleno) ${ }^{15}$, de 13 de diciembre, sobre la condición de acto firme de las conclusiones de una comisión de investigación a los efectos de su impugnación y el dies a quo del cómputo del plazo de tres meses para la interposición de la demanda.

Por lo que se refiere a la condición de decisión o acto firme de las conclusiones de una comisión de investigación, el TC afirma que las comisiones de investigación son órganos internos de las Cámaras, cuyos «dictámenes constituyen documentos de trabajo que han de ser sometidos a debate y votación de la Cámara en Pleno», de modo que «la decisión del Pleno es el acto que expresa la voluntad de la Cámara con la que concluye la actividad parlamentaria de investigación». Así pues, el dictamen de una comisión de investigación en tanto que acto parlamentario preparatorio o de trámite de la decisión del Pleno no se puede considerar acto firme en el sentido del art. 42 LOTC a los efectos de su impugnación en amparo. El acto que puede constituir objeto de un recurso de amparo es la resolución o decisión del Pleno sobre las conclusiones de la comisión con el que finaliza la actividad investigadora de la Cámara. No obstante, el posible error del demandante de amparo al identificar como objeto del recurso las conclusiones de la comisión de investigación en vez de la decisión del Pleno de la Cámara no puede determinar la inadmisión del recurso de amparo cuando aquel error no impida al TC conocer que es lo que de él se pide ni la causa de la petición (FJ 2 a).

15 Véanse infra pp. 291-293. 
En cuanto al dies a quo del plazo de tres meses que establece el art. 42 LOTC para la interposición de la demanda de amparo, el TC entiende que si bien dicho plazo ha de computarse con carácter general desde la fecha de notificación mediante la correspondiente comunicación del acto que se pretende recurrir o desde su publicación en el boletín oficial de la Cámara, esta publicación oficial no es suficiente a los efectos de iniciar el cómputo del referido plazo en los supuestos de personas ajenas a la Cámara que resulten directamente afectadas por las conclusiones de una investigación parlamentaria. El TC considera que en estos casos, dado el carácter fundamentalmente interno de los boletines oficiales de las Asambleas legislativas, «no cabe imponer a los ciudadanos ajenos a la Cámara, por excesiva, la carga de su seguimiento y lectura para conocer si han podido resultar afectados o no y, en su caso, en qué términos por las conclusiones de una posible investigación parlamentaria». Así pues, el cómputo del plazo de tres meses se ha de iniciar en estos supuestos «a partir de la notificación mediante la correspondiente comunicación de las conclusiones de investigación a las personas ajenas a la Cámara que pueden resultar afectadas por ellas» (F J 3).

6. El TC durante este cuatrimestre ha comenzado a resolver algunos de la cerca de treintena de recursos de amparo interpuestos en relación con la causa seguida ante la Sala de lo Penal del Tribunal Supremo por delitos de rebelión, sedición, malversación de caudales públicos y desobediencia como consecuencia del denominado proceso soberanista en Cataluña.

Las SSTC 129 a 131/2018 (Pleno), de 12 de diciembre, inadmiten tres recursos de amparo promovidos contra las resoluciones de la Sala de lo Penal del Tribunal Supremo que declaran la competencia de este órgano jurisdiccional para la instrucción y el enjuiciamiento de la causa penal.

La cuestión nuclear examinada gira en torno a la posibilidad de impugnar en amparo por supuestas vulneraciones de derechos fundamentales resoluciones interlocutorias dictadas en un proceso penal en curso. En las sentencias se da cuenta de la evolución de la jurisprudencia constitucional en la materia, que, tras una etapa inicial sin cuestionar el carácter prematuro de las demandas de amparo contra este tipo de resoluciones, ha venido manteniendo, como regla general desde el ATC 361/1993, de 13 de diciembre, y la STC 147/1994, de 2 de mayo, que en aquellos casos en los que el proceso penal aún no esté concluido por decisión que se pronuncie sobre la condena o absolución, e incluso en los que la celebración del juicio oral no ha tenido lugar, resulta prematura la invocación de lesiones de derechos fundamentales o libertades públicas que pueden ser examinadas ulteriormente en el curso del proceso. En otras palabras, como se recuerda en las sentencias reseñadas, trayendo a colación una reiterada doctrina 
constitucional, «el marco natural en el que ha de intentarse la reparación del derecho constitucional vulnerado por el órgano jurisdiccional es el mismo proceso judicial previo, de tal modo que, en principio, sólo cuanto éste haya finalizado por haber recaído una resolución firme y definitiva puede entenderse agotada la vía judicial y, consecuentemente, es posible acudir ante este Tribunal en demanda de amparo» (SSTC 128/2018, FJ 5; 130/2018, FJ 5, y 131/2018, FJ 5).

En las sentencias se recuerdan los siguientes tres supuestos excepcionales en los que, conforme a la jurisprudencia constitucional, puede acudirse en amparo aun no habiendo concluido el proceso penal: i) cuando las resoluciones judiciales afecten a derechos fundamentales de carácter sustantivo (derecho a la libertad personal y a la libertad sindical [SSTC 128/1995, de 26 de julio, y 27/1997, de 1 de febrero]); ii) cuando la vulneración de derechos procesales alegada sea actual y hubiera sido analizada y resuelta de forma firme y definitiva en la vía judicial a través de los cauces legalmente establecidos, de forma que ya no puede ser reparada en el proceso judicial en el que se ha producido (manifestaciones del derecho a la defensa y asistencia letrada en proceso penal, como denegación de nombramiento de intérprete [STC 71/1988, de 19 de abril]; denegación de personación en causa penal tras orden de busca y captura del declarado rebelde [STC 24/2018, de 5 de marzo]; y derecho al juez ordinario determinado por la ley en los supuestos en los que se reclama la actuación de la jurisdicción ordinaria frente a la jurisdicción militar [SSTC 161/1995, de 7 de noviembre; 18/2000, de 31 de enero]); iii) supuestos de revocación de sentencias penales absolutorias que habilitan la posibilidad de un nuevo enjuiciamiento (STC 129/2018, FJ 6; 130/2018, FJ 5, y 131/2018, FJ 5).

A la luz de la doctrina constitucional expuesta, el TC enjuicia las quejas de las demandantes de amparo, que denuncian, en primer término, una lesión del derecho a un proceso con todas las garantías, en su vertiente de derecho al juez imparcial (art. 24.2 CE), por falta de imparcialidad de la Sala porque la acción penal había sido impulsada e iniciada por quien entonces era fiscal general del Estado y que, con anterioridad a ocupar este cargo, había formado parte de la Sala. El TC inadmite esta queja, además de por no haberse invocado la lesión del derecho fundamental vulnerado en la vía judicial previa (art. 44.1.c LOTC), sino por vez primera con ocasión de la demanda de amparo (STC 129/2018, FJ 3), por falta de agotamiento de esta vía judicial (art. 44.1.a LOTC), al no haber promovido incidente de recusación, que es el cauce procesal a través del que han de hacerse valer las dudas sobre la imparcialidad judicial. A lo que se añade que la resolución judicial que en una causa penal pone término al incidente de recusación no supone el 
agotamiento tampoco de la vía judicial previa, pues si se llega a decretar la apertura del juicio oral «en su fase preliminar, tanto en el procedimiento abreviado, como en el proceso ordinario por delito a través de la cuestiones de previo pronunciamiento [...], es posible hacer valer y obtener la reparación de las supuestas vulneraciones de derechos fundamentales que se aleguen por las partes». Y la apreciación de la falta de agotamiento de la vía judicial previa en tales supuestos se refiere tanto «al pronunciamiento de fondo sobre la apariencia de imparcialidad que se cuestione» como "a las supuestas vulneraciones de derechos procesales que se alegue se hubieran producido durante la tramitación del incidente de recusación» (SSTC 129/2018, FJ 3; 130/2018, FJ 6, y 131/2018, FJ 6).

Igual suerte ha tenido la segunda de las quejas de los recursos, referida a la supuesta vulneración del derecho al juez ordinario predeterminado por la ley (art. 24.2 CE), al considerar las demandantes que la competencia para conocer de la causa competía en razón del aforamiento de algunos de los investigados al Tribunal Superior de Justicia de Cataluña en vez de al Tribunal Supremo. En efecto, el TC considera que la queja es prematura atendiendo al momento procesal en el que se ha suscitado, ya que permanece abierto el cauce procesal legalmente pertinente en el que dilucidar la cuestión en la vía judicial previa, como es el planeamiento ante el Tribunal de enjuiciamiento de un artículo de previo y especial pronunciamiento que solicite la declinatoria de jurisdicción. En ese momento procesal, el Tribunal a quo puede resolver la cuestión planteada y, a partir de esa decisión, puede ser evaluada su resolución desde el contenido del derecho al juez ordinario predeterminado por la ley (SSTC 129/2918, FJ 7; 130/2018, FJ 7, y 131/2018, FJ 7).

7. El TC ha recurrido de nuevo a la denominada «reviviscencia» del incidente de nulidad de actuaciones para acordar la inadmisión de una demanda de amparo por falta de agotamiento de la vía judicial previa.

En efecto, en la STC 95/2018 (Sala Primera), de 17 de septiembre, se inadmite a trámite por falta de agotamiento de la vía judicial previa la demanda de amparo en relación con la decisión del Tribunal Supremo de inadmitir un recurso de casación para la unificación de la doctrina, por no haber promovido el recurrente el incidente de nulidad de actuaciones en relación con la lesión autónoma que con carácter directo le imputaba a aquella decisión. E igual causa de inadmisión se aprecia en relación con la impugnación por incurrir en incongruencia omisiva de la sentencia del Tribunal Superior de Justicia que confirmó la del Juzgado de lo Social que declaró improcedente el despido del demandante de amparo, por no haber promovido 
incidente de nulidad de actuaciones contra la sentencia de apelación tras haberle sido inadmitido el recurso de casación (FJ 2) ${ }^{16}$.

8. Desde la perspectiva de la subsidiariedad del recurso de amparo en el aspecto relativo también al agotamiento de la vía judicial previa ha de traerse a colación la STC 101/2018 (Sala Segunda), de 1 de octubre, en la que se aborda lo que denomina "efecto arrastre» de la falta de interposición de un recurso o de un remedio procesal ${ }^{17}$.

La Sala considera que si esa falta de agotamiento afecta únicamente a la última resolución judicial la demanda de amparo satisface el requisito de la subsidiariedad respecto del resto de las lesiones imputables a las resoluciones judiciales precedentes si fueron pertinentemente denunciadas y respecto a ellas se ha agotado la vía judicial. Por el contrario, entiende que la inadmisión de todos los motivos del recurso de amparo por esa falta de agotamiento de la vía judicial constituye un resultado formalista y desproporcionado a la diligencia del recurrente.

Formalista porque dicha exigencia es de dudosa utilidad práctica, ya que, conforme al criterio de la mayor retroacción de las actuaciones en el orden de tratamiento de las quejas, de prosperar las lesiones denunciadas imputables a las resoluciones precedentes a la que pone fin a la vía judicial, resultaría innecesario un pronunciamiento sobre la existencia de la lesión posterior acumulada, normalmente procesal. Además los resultados resultarían paradójicos, pues el recurrente que se aquieta a la última vulneración y decide no denunciarla vería su demanda de amparo admitida. Sin embargo, quien denuncia en la demanda de amparo la lesión causada por la última resolución judicial, aunque sea una denuncia meramente incidental, vería su demanda inadmitida por no haber agotado la vía judicial (FJ 2) ${ }^{18}$.

16 Además de por las indicadas causas de inadmisión, la demanda también se inadmite por no haber satisfecho el recurrente el requisito de haber invocado ante los órganos judiciales la vulneración del derecho fundamental «tan pronto como», una vez conocida, hubiera lugar para ello (art. 44.1.c LOTC).

17 La aplicación de esta doctrina del denominado «efecto arrastre» ha llevado al TC en el ATC 116/2018 (Sección Cuarta), de 17 de octubre, a estimar el recurso de súplica interpuesto por el Ministerio Fiscal contra una providencia de inadmisión de un recurso de amparo por no haber promovido contra la última resolución judicial el incidente de nulidad de actuaciones. Doctrina no aplicable a aquellos supuestos en los que el recurso interpuesto contra la última resolución judicial es inadmitido a trámite no por ser legalmente improcedente, sino por la defectuosa interposición del recurso, sin que el demandante de amparo haya reaccionado frente a la decisión de inadmisión (ATC 132/2018 [Sección Cuarta], de 19 de diciembre).

18 Juan Carlos Duque Villanueva. 


\section{FUENTES DEL DERECHO}

1. La STC 128/2018 (Pleno), de 29 de noviembre, descarta que la reforma de 2015 del recurso de casación contencioso-administrativo vulnere la reserva de ley orgánica del art. 122.1 CE, en lo que atañe a la competencia para conocer del nuevo recurso de casación basado en la infracción de normas emanadas de la comunidad autónoma. El art. 86.3 de la Ley reguladora de la Jurisdicción Contencioso-administrativa determina tras esa reforma que la competencia para conocer de dicho recurso corresponde a una sección de la Sala de lo Contencioso-administrativo del Tribunal Superior de Justicia, y si hubiera más de una sección, la Sala de Gobierno establecerá el turno correspondiente. El órgano judicial promotor de la cuestión sostenía que esa regulación no puede contenerse en una ley ordinaria, al estar reservada por el art. 122.1 CE a la Ley Orgánica del Poder Judicial (LOPJ).

Tras recordar la doctrina constitucional sobre el alcance de la específica reserva de ley orgánica que establece el art. 122.1 CE (SSTC 224/1993, de 1 de julio, FJ 3; 54/1994, de 21 de septiembre, FJ 4, y 121/2011, de 7 de julio, FJ 3), la STC 128/2018 advierte que en el contenido mínimo indispensable de esa ley orgánica no se incluyen aspectos tales como las modalidades de recurso disponibles, las resoluciones en su caso recurribles, los órganos competentes para su resolución o los procedimientos que a tal fin deban seguirse, con independencia de que las disposiciones de la LOPJ hayan procedido en ocasiones en el pasado a precisar, en mayor o menor grado, algunos de esos aspectos, pues el contenido mínimo indispensable no es un límite para el legislador orgánico y sí para el legislador ordinario. Fuera de ese contenido mínimo indispensable reservado a la LOPJ, la jurisprudencia constitucional siempre ha admitido la posibilidad de que el legislador ordinario concrete ese diseño básico de la organización judicial. Esto es lo que acontece en el caso enjuiciado, debiendo entenderse que las secciones a las que se refiere el precepto cuestionado son una variedad de las secciones «funcionales» que contempla la LOPJ, por lo que no constituyen órganos judiciales distintos a los efectos de la doctrina constitucional sobre el alcance de la reserva de ley orgánica que deriva del art. 122.1 CE y que, por tanto, no necesariamente han de ser reguladas por disposiciones de rango orgánico. Ello conduce al rechazo de la duda de constitucionalidad (FJ 4$)^{19}$.

19 La STC 128/2018 cuenta con dos votos particulares, en los que los magistrados disidentes consideran que debió estimarse la cuestión, al entender que las secciones a las que se refiere el precepto cuestionado no son meras divisiones funcionales de las salas 
Descarta asimismo la STC 128/2018 que el precepto cuestionado incurra en infracción del principio de seguridad jurídica (art. 9.3 CE), por la falta de mención de las resoluciones objeto del recurso de casación autonómica y la disparidad de criterios de aplicación existentes entre los Tribunales Superiores de Justicia. La simple constatación de problemas interpretativos en relación con una norma legal no supone necesariamente una infracción del principio de seguridad jurídica. La indeterminación del precepto cuestionado no conlleva una quiebra de dicho principio, pues una interpretación sistemática y razonable permite acotar su sentido y determinar las resoluciones que pueden ser objeto de recurso y el órgano judicial que ha de resolverlo (FJ 5).

La apreciación de la infracción del principio de seguridad jurídica (art. 9.3 CE), en conexión con la reserva específica de ley orgánica de los arts. 117.2 y 122.1 CE en lo que atañe a la regulación del estatuto de jueces y magistrados, determina que la STC 135/2018 (Pleno), de 13 de diciembre, declare la inconstitucionalidad y nulidad del art. 367.1 LOPJ (y por conexión de sendos incisos del art. 367.2 LOPJ). El precepto exigía, para el reingreso en el servicio activo de los jueces y magistrados suspensos, la previa declaración de aptitud por el Consejo General del Poder Judicial. La STC 135/2018 considera que el precepto cuestionado no ofrece seguridad jurídica, pues no permite definir qué debe entenderse por aptitud y, en consecuencia, cuáles son los parámetros para valorar la idoneidad, suficiencia o capacidad de quien pretenda dicha declaración; tampoco precisa la situación en la que queda el juez o magistrado suspenso que pretende reingresar al servicio activo y no obtiene la declaración de aptitud (FJ 7).

2. La cuestión de los límites materiales de las leyes de presupuestos se aborda durante el período comprendido en esta crónica en tres pronunciamientos (SSTC 99/2018, de 19 de septiembre, 122/2018, de 31 de octubre, y 141/2018, de 20 de diciembre).

La STC 122/2018 (Pleno), de 31 de octubre, se ocupa del problema de los límites materiales de las leyes de presupuestos estatales, en un recurso de inconstitucionalidad interpuesto por más de cincuenta diputados contra determinados preceptos de la Ley 3/2017, de 27 de junio, de Presupuestos Generales del Estado para el año 2017, relativos a las limitaciones a la incorporación de personal laboral al sector público en situaciones de cambio de modalidad de gestión de servicios públicos y de extinción de contratos de obras públicas, y a la exigencia de responsabilidades a las Administraciones

de lo Contencioso-administrativo, sino órganos judiciales nuevos, cuya constitución está reservada a la Ley Orgánica del Poder Judicial por el art. 122.1 CE. 
públicas y entidades dependientes por la utilización indebida de la contratación laboral.

Recuerda el TC su reiterada doctrina conforme a la cual la modificación de los preceptos de una ley de presupuestos tras la interposición del recurso de inconstitucionalidad no determina la pérdida de objeto de este, cuando lo controvertido es precisamente si esos preceptos pueden ser válidamente incluidos en una ley de presupuestos (FJ 2). Seguidamente, la STC 122/2018 trae a colación la igualmente conocida jurisprudencia constitucional acerca de los límites materiales de las leyes de presupuestos, contenidos para las leyes de presupuestos generales del Estado en el art. 134 CE (FJ 3). De acuerdo con esta doctrina, las leyes de presupuestos tienen un contenido esencial, indisponible para el legislador, que viene integrado por la previsión de ingresos y la habilitación de gastos, así como por las normas que directamente desarrollan o aclaran las partidas presupuestarias en que el gasto público se concreta, esto es, el presupuesto en sí. Pueden tener, además, un «contenido eventual», referido a preceptos que regulen materias en las que exista una relación inmediata y directa con los ingresos y gastos que integran el presupuesto y cuya inclusión en la ley de presupuestos esté justificada por ser esos preceptos complemento necesario para la mayor inteligencia y para la mejor ejecución del presupuesto y, en general, de la política económica del Gobierno. No basta, por tanto, que la medida normativa pueda tener alguna incidencia en los ingresos o los gastos públicos, pues toda medida es susceptible de tener un impacto presupuestario, de manera que, si esto fuera suficiente para su inclusión en la ley de presupuestos, los límites materiales que afectan a las leyes de presupuestos quedarían desnaturalizados, diluyéndose hasta devenir prácticamente inoperantes.

Como es obvio, la aplicación de esta doctrina a las diferentes controversias planteadas ha dado lugar a una amplia casuística, como recuerda también el Tribunal Constitucional. En el caso enjuiciado, la STC 122/2018 concluye que las medidas legislativas discutidas no pueden considerarse contenido eventual de la ley de presupuestos, pues aunque pudieran eventualmente tener algún efecto sobre el gasto público, ese efecto no es inmediato ni directo. Tampoco constituyen un complemento necesario de la política económica del Gobierno ni se orientan a la mayor inteligencia y mejor ejecución del presupuesto. Se trata, en suma, de medidas regulatorias de carácter sustantivo que, de acuerdo con la doctrina citada, resultan ajenas al contenido propio de las leyes de presupuestos, lo que determina la estimación del recurso (FJ 4).

La STC 99/2018 (Pleno), de 19 de septiembre ${ }^{20}$, aborda también la cuestión de los límites materiales de las leyes de presupuestos, si bien en este caso

20 Véase supra p. 254 
en relación con los presupuestos autonómicos, en un recurso de inconstitucionalidad interpuesto por el Defensor del Pueblo contra una disposición de una ley de presupuestos autonómica que regula la exención de guardias del personal estatutario sanitario de atención especializada.

Descarta la STC 99/2018 que el recurso haya perdido objeto por el hecho de que la disposición impugnada haya sido derogada por una ley de presupuestos autonómica posterior, pues ello supondría negar la posibilidad de control de las normas con vigencia limitada en el tiempo, como lo son las de contenido presupuestario, creándose así un ámbito normativo inmune al control de la jurisdicción constitucional (FJ 2) ${ }^{21}$.

Recuerda asimismo la STC 99/2018 que el art. 134 CE regula una institución estatal, la ley de presupuestos generales del Estado, que, como regla general, no resulta aplicable sin más a los presupuestos de las comunidades autónomas, a los que serán de aplicación las disposiciones de la Ley Orgánica de Financiación de las Comunidades Autónomas y de su respectivo estatuto de autonomía. De este modo, los límites al contenido posible o eventual de la ley de presupuestos estatal derivados del art. $134 \mathrm{CE}$ lo serán también para las leyes de presupuestos autonómicas siempre que haya identidad sustancial en las normas que integren el bloque de la constitucionalidad aplicable (FJ 5).

En el caso enjuiciado, el TC aprecia que concurre esa identidad sustancial, lo que determina la aplicación de la doctrina sobre límites materiales de las leyes de presupuestos, en particular en lo que atañe al contenido posible o eventual, que es lo que se controvierte en relación con el precepto impugnado. Ello conduce a que la STC 99/2018 estime el recurso, al entender que la disposición cuestionada regula una cuestión referida a la determinación de las condiciones de trabajo del personal sanitario que no puede ser considerada como contenido eventual de la ley de presupuestos, ya que no guarda relación directa con los ingresos o gastos de la comunidad autónoma, ni sirve de vehículo director de la política económica del Ejecutivo autonómico, ni contribuye a una mayor inteligencia o mejor ejecución del presupuesto (FJ 6).

En fin, la STC 141/2018 (Pleno), de 20 de diciembre, se ocupa también de la cuestión de los límites materiales de las leyes de presupuestos de las comunidades autónomas, en un recurso de inconstitucionalidad interpuesto por el Defensor del Pueblo contra una disposición de una ley de presupuestos de la comunidad autónoma de Cataluña que atribuye al llamado «plan Serra

21 La STC 99/2018 cuenta con un voto particular en el que se sostiene que el TC debió declarar la extinción del recurso de inconstitucionalidad por pérdida de objeto. 
Húnter» la condición de instrumento prioritario para la contratación de personal docente e investigador en las universidades públicas catalanas. Proyectando al caso la conocida doctrina constitucional antes recordada, la STC 141/2018 concluye que la disposición impugnada tiene cabida en la ley de presupuestos como contenido adicional de esta. Aunque no se trata propiamente de una restricción a la contratación derivada de la limitación de la tasa de reposición de efectivos (técnica esta de contención del gasto en materia de personal que puede ser incluida en las leyes de presupuestos por su innegable impacto en la política presupuestaria), sino de la implantación de un modelo de provisión de plazas de personal docente e investigador basado principalmente en la contratación laboral, lo cierto es, entiende el TC que el precepto contribuye a la mejor inteligencia del presupuesto (FJ 5).

3. Acerca de la concurrencia del presupuesto habilitante para la aprobación de decretos leyes por las comunidades autónomas se pronuncia la STC 105/2018 (Pleno), de 4 de octubre ${ }^{22}$, que resuelve el recurso de inconstitucionalidad interpuesto por el presidente del Gobierno contra el art. 1 del Decreto Ley de la Generalitat de Cataluña 5/2017, de 1 de agosto, de medidas urgentes para la ordenación de los servicios de transporte de viajeros en vehículos de hasta nueve plazas. El precepto impugnado regula la transmisión de autorizaciones de alquiler de vehículos de turismo con conductor, estableciendo una prohibición temporal (de dos años de duración a partir del otorgamiento efectivo) para la transmisión de las autorizaciones domiciliadas en Cataluña.

La STC 105/2018, aplicando la reiterada doctrina constitucional sobre el canon de enjuiciamiento en estos supuestos, concluye, tras examinar las justificaciones ofrecidas en el preámbulo del decreto ley impugnado y en la intervención del Ejecutivo autonómico en el trámite de convalidación ante el Parlamento de Cataluña, que el Gobierno de la Generalitat ha acreditado la concurrencia del presupuesto habilitante de la extraordinaria y urgente necesidad, exigido por los arts. 86.1 CE y 64 del Estatuto de Autonomía de Cataluña, para adoptar la medida impugnada. La introducción de un límite temporal a las transmisiones de las autorizaciones otorgadas que establece la norma impugnada, que modifica de manera inmediata la regulación precedente,

[...] responde a la exigencia de ordenar el sector de las autorizaciones VTC para garantizar una convivencia ordenada de las diversas modalidades de transporte de viajeros. La reforma debía acometerse en un plazo tasado para anticiparse a

22 Véanse infra pp. 275-278. 
las sentencias que debían resolver sobre las autorizaciones masivamente solicitadas durante el periodo de tiempo en que no existieron restricciones cuantitativas a su otorgamiento, una gran parte de las cuales, se pronosticaba, no respondían a un interés real de realizar la actividad de transporte, sino a obtener ganancias con su transmisión (FJ 4).

Queda así rechazada la pretendida infracción del requisito del presupuesto habilitante del decreto ley, si bien finalmente la STC 105/2018 declara la inconstitucionalidad del precepto impugnado por invadir la competencia estatal exclusiva sobre los transportes terrestres que transcurren por más de una comunidad autónoma (art. 149.1.21 CE), como asimismo solicitaba el recurrente.

4. La STC 98/2018 (Pleno), de 19 de septiembre, que resuelve un recurso de inconstitucionalidad promovido por más de cincuenta diputados contra una ley aragonesa reguladora del impuesto sobre contaminación de las aguas, recuerda que, conforme a reiterada jurisprudencia constitucional, el derecho de la Unión Europea no se integra (ni en virtud del art. 93 CE ni del art. 96.1 $\mathrm{CE}$ ) en los parámetros de constitucionalidad a que están sometidas las leyes; en consecuencia, el TC rechaza entrar a conocer de la alegada vulneración del principio de interdicción de la arbitrariedad de los poderes públicos (art. 9.3 $\mathrm{CE}$ ), en aquellos aspectos que se apoyan en la pretendida infracción del derecho de la Unión Europea (FJ 2).

Fuera de este aspecto, la STC 98/2018 sí entra a enjuiciar, para descartarla, la supuesta infracción del principio de interdicción de la arbitrariedad de los poderes públicos que asimismo alegan los diputados recurrentes, bajo la premisa de que el sistema de bonificaciones del impuesto que establece la normativa impugnada no se basa en criterios razonables. Recuerda el TC que la calificación de «arbitraria» dada a una ley exige una cierta prudencia, toda vez que es la expresión de la voluntad popular, por lo que su control de constitucionalidad debe ejercerse sin imponer restricciones indebidas al Poder Legislativo y respetando sus opciones políticas, centrándose en verificar si el precepto cuestionado establece una discriminación —que entraña siempre una arbitrariedad-o bien, si aun no estableciéndola, carece de toda explicación racional —lo que también supone una arbitrariedad-, sin que sea pertinente un análisis a fondo de todas las motivaciones posibles de la norma y de todas sus eventuales consecuencias. Conforme a este canon de enjuiciamiento, la STC 98/2018, tras examinar detalladamente el régimen de bonificaciones que establece la ley impugnada, concluye que el legislador autonómico ha atendido a diversas consideraciones 
de orden económico, social y de población, que no carecen de justificación razonable, lo que excluye el reproche de arbitrariedad que formulan los recurrentes (FJ 5).

Descarta asimismo la STC 98/2018 que la normativa impugnada incurra en infracción del principio de seguridad jurídica (art. 9.3 CE), en su vertiente de protección de la confianza legítima. Tras exponer la doctrina constitucional sobre este principio constitucional, la STC 98/2018 concluye que no existe la vulneración alegada por los recurrentes, basada en que el legislador autonómico habría dado un giro radical a la regulación del impuesto, pasando de un régimen convenido con los municipios (en particular con el de Zaragoza) a un sistema uniforme que no tiene en cuenta situaciones como el esfuerzo inversor, la posición geográfica o la carga contaminante de cada localidad, y que establece bonificaciones ligadas a la existencia o no de instalaciones de depuración. Señala la STC 98/2018 que los recurrentes no precisan qué expectativas legítimas de los contribuyentes afectados podrían entenderse amparadas por la normativa precedente, y que no sería coherente con el carácter dinámico del ordenamiento jurídico y con la jurisprudencia constitucional considerar contrario al principio de seguridad jurídica el cambio normativo que se discute. En consecuencia, se concluye que «la regulación impugnada se enmarca en el margen de configuración del legislador, que tiene plena libertad para elegir entre las distintas opciones posibles dentro de la Constitución» (FJ 6).

Los principios de seguridad jurídica e interdicción de la arbitrariedad (art. 9.3 CE) también son tenidos en cuenta como canon de control de constitucionalidad en la STC 140/2018 (Pleno), de 20 de diciembre, que resuelve el recurso de inconstitucionalidad promovido por más de cincuenta diputados contra la reforma de la Ley Orgánica del Poder Judicial en relación con la jurisdicción universal. Los diputados recurrentes consideraban que, en la medida en que esa reforma restringe el ámbito de la extensión extraterritorial de la jurisdicción penal espańola previsto en la regulación precedente de la LOPJ, se produce un efecto de regresividad atentatorio de los principios de interdicción de la arbitrariedad y de seguridad jurídica. La STC 140/2018 descarta esa pretendida vulneración, partiendo de la conocida doctrina sobre el alcance de los principios proclamados por el art. 9.3 CE como parámetro de control estricto de la constitucionalidad de las leyes; ese control debe ejercerse por el TC de forma que no imponga constricciones indebidas al Poder Legislativo y respete sus opciones políticas $(\mathrm{FJ} 7)^{23}$.

23 Herminio Losada González. 


\section{ESTRUCTURA TERRITORIAL DEL ESTADO}

1. Se constata en los últimos meses una disminución de aquellos conflictos planteados por los actores territoriales pendientes de finalización ante el TC. Así, a fecha 31 de enero de 2019, el TC tiene pendientes de resolver únicamente trece asuntos planteados por el Estado frente a disposiciones o actos autonómicos (ya sea vía recurso de inconstitucionalidad [doce asuntos pendientes] o vía impugnación de disposiciones autonómicas [un asunto pendiente]) y ocho asuntos planteados por las comunidades autónomas frente a disposiciones del Estado (se trata de seis recursos de inconstitucionalidad y de dos conflictos positivos de competencia). Más allá del número total de asuntos pendientes es interesante destacar que la mayoría de ellos son conflictos relativamente cercanos en el tiempo, pues en lo que se refiere a las impugnaciones del Estado se trata de disposiciones autonómicas de los años 2017 y 2018, y en lo que se refiere a las impugnaciones de las comunidades autónomas se trata de disposiciones estatales de 2015, 2016 y 2017 — si bien queda pendiente de resolución, como caso patológico, una impugnación de una disposición de 2010 de Navarra de la Ley Orgánica 2/2010, de 3 de marzo, de salud sexual y reproductiva-.

Los datos referidos muestran una disminución evidente de la conflictividad pero sobre todo permiten apreciar una interesante disminución en los tiempos de resolución de las cuestiones territoriales ante el TC, lo que le permitirá en el futuro cumplir mejor su papel en la resolución de aquellas, pues ello depende en buena medida de la celeridad de sus pronunciamientos.

2. Cabe examinar en primer lugar alguna de las cuestiones planteadas en la STC 97/2018 (Pleno), de 19 de septiembre ${ }^{24}$, por la que se resuelve el recurso de inconstitucionalidad interpuesto por la presidenta del Gobierno en funciones contra diversos preceptos de la Ley 3/2015, de 18 de junio, de vivienda del País Vasco.

Así, interesa examinar la impugnación de la disposición adicional primera, apdo. tercero, párrs. segundo y cuarto, de la Ley vasca 3/2015, que, al regular la prestación de servicios inmobiliarios, se refiere a la «necesidad de suscribir una nota de encargo entre el profesional y el usuario del servicio», así como a la creación de un «distintivo», que «deberá figurar en el papel comercial y en la publicidad de los agentes», y una "placa de formato», que «tendrá que ser colocada en lugar visible para el público en cada uno de los locales del agente inmobiliario o agencia inscrita».

24 Véase supra p. 254. 
El recurso impugna el referido precepto autonómico por vulnerar el art. 5 de la Ley 20/2013, de 9 de diciembre, de Garantía de la Unidad de Mercado (LGUM). Precepto declarado básico y que admite en su apdo. 1 que las autoridades autonómicas establezcan límites o requisitos «al acceso a una actividad económica o su ejercicio", para salvaguardar "razones imperiosas de interés general», entre ellas —y por remisión al art. 3.11 de la Ley 17/2009, de 23 de noviembre, sobre el libre acceso a las actividades de servicios y su ejercicio-, «la protección de los derechos, la seguridad y la salud de los consumidores» $\mathrm{y}$ "las exigencias de la buena fe en las transacciones comerciales» (art. 5.1). De acuerdo con el apdo. 2 de ese mismo art. 5, en todo caso, «cualquier límite o requisito" "deberá ser proporcionado a la razón imperiosa de interés general invocada, y habrá de ser tal que no exista otro medio menos restrictivo o distorsionador para la actividad económica».

Recordemos que en este punto el TC ha señalado cómo el escrutinio al que se someten las regulaciones autonómicas que restringen el ejercicio de una actividad económica es más incisivo en la normativa básica estatal (LGUM) que el que se deriva del art. $38 \mathrm{CE}$. Así lo recuerda de nuevo la STC 97/2018 cuando señala que la Ley 20/2013 ha elevado «el estándar mínimo de protección que garantiza el artículo 38 CE» (STC 111/2017, de 5 de octubre, FJ 4 b), citando las SSTC 97/2017, de 17 de julio, FJ 4, y 89/2017, de 4 de julio, FF. JJ. 13 a 15).

Pero lo que tiene interés de la STC 97/2018 es que da un paso más en la interpretación del parámetro de control establecido en la legislación básica del Estado al desestimar la impugnación por falta de carga probatoria de la desproporción de la regulación autonómica por parte del recurrente. Así considera el TC que la demanda nada ha razonado sobre si la exigencia de una nota de encargo, un distintivo y una placa de formato incumplen el art. 5.2 de la Ley 20/2013 por inadecuadas, innecesarias o desproporcionadas. Para el TC la denuncia de una invasión competencial como esta - fundada en la eventual contradicción entre la regulación autonómica de límites a la libertad económica y la exigencia básica de proporcionalidad- ha de ir acompañada de un juicio ponderativo específico - ilustrado, en la medida de lo posible, con datos y análisis económicos rigurosos- sobre la idoneidad, necesidad y proporcionalidad de la restricción impugnada.

Así, la STC 97/2018 establece de forma clara, y por vez primera en su jurisprudencia, que la carga de probar que una medida autonómica susceptible de restringir el acceso a una actividad económica o su ejercicio es proporcionada a la razón imperiosa de interés general invocada corresponde al que la impugna, en este caso al Estado, el cual deberá acompañar la impugnación de un juicio ponderativo específico, con datos y análisis económicos rigurosos, 
afirma el TC, sobre la idoneidad, necesidad y proporcionalidad de la restricción impugnada.

El TC parece retractarse de la referida doctrina solo unas pocas sentencias más tarde; en la STC 134/2018 (Pleno), de 13 de diciembre, al declarar inconstitucional, sin exigir que sea el recurrente el que motive la desproporción, el art. 4 de la Ley 9/2017, de 3 de agosto, de regulación de las corridas de toros y de protección de los animales en las Illes Balears, que determina que, para que la duración del viaje desde la ganadería hasta la plaza de toros sea la mínima indispensable, la ganadería suministradora de los toros será la más cercana en términos de distancia a la plaza de toros donde se celebre el espectáculo taurino.

Sin embargo, aunque el TC no lo explicite así, cabe justificar la diferencia en la exigencia de probar la desproporción de la medida en el hecho de que, en el supuesto de la STC 134/2018, la regulación autonómica, más allá de vulnerar la normativa básica estatal — recogida en el art. 5 de la LGUMpor restringir en general el ejercicio de una actividad económica, es susceptible de vulnerar también el art. 139.2 CE, por tener efectos restrictivos más onerosos sobre los operadores económicos de fuera de la comunidad autónoma que sobre los de dentro. En efecto, en el caso de las regulaciones que tienen este tipo de efectos "proteccionistas" cabe considerar que se debe invertir la carga de la prueba y debe ser el poder público que establece la restricción el que justifique la proporcionalidad de la misma.

Así, de acuerdo con la doctrina más reciente del TC, STC 111/2017, el art. 139.2 CE es un precepto cuyo objetivo sería garantizar la libre circulación de personas y bienes entre las comunidades autónomas, lo cual se concreta en ser un precepto que prohíbe los «obstáculos al comercio interautonómico» injustificados y no en ser un precepto que prohíba los «obstáculos al comercio en general» injustificados.

La diferencia entre ambos conceptos — «obstáculo al comercio interautonómico» $\mathrm{y}$ «obstáculo al comercio en general»— radicaría en que para que se produzca un "obstáculo al comercio interautonómico» es necesario que se dé un efecto restrictivo diferenciado más oneroso sobre la circulación de bienes o personas de fuera que sobre la circulación de bienes o personas de dentro, mientras que para que se produzca un «obstáculo al comercio en general» basta que se dé un efecto restrictivo de la circulación de bienes o personas en general.

El escrutinio jurisdiccional al que se someten las regulaciones públicas bajo el art. 139.2 CE — un escrutinio de proporcionalidad — es, en principio, más estricto que el que se realiza bajo el art. $38 \mathrm{CE}$ - un escrutinio de mera razonabilidad-, tal como recuerda la STC 111/2017. Y si bien el escrutinio al 
que se someten las regulaciones que obstaculizan el comercio entre comunidades autónomas bajo el art. 139.2 CE es parecido al escrutinio al que se someten bajo el art. 5 de la LGUM - también un escrutinio de proporcionalidad - aquellas regulaciones públicas que restringen en general el ejercicio de la actividad económica, la diferencia entre la aplicación de la normativa básica y la del art. 139.2 radicará en a quién corresponde probar la proporción o desproporción de la medida restrictiva.

3. La STC 105/2018 (Pleno), de 4 de octubre ${ }^{25}$, resuelve el recurso de inconstitucionalidad promovido por el presidente del Gobierno contra el art. 1 del Decreto Ley de la Generalitat de Cataluña 5/2017, de 1 de agosto, de medidas urgentes para la ordenación de los servicios de transporte de viajeros en vehículos de hasta nueve plazas, en el que se establece una prohibición temporal, de dos años de duración a partir del otorgamiento efectivo, para la transmisión de aquellas autorizaciones domiciliadas en Cataluña que habilitan para la prestación de servicios de transporte de viajeros en la modalidad de alquiler de vehículos con conductor. La STC 105/2018 estima el recurso de inconstitucionalidad y declara la inconstitucionalidad y nulidad del precepto impugnado.

El recurso plantea dos tipos de tachas de inconstitucionalidad, las de orden competencial y las de orden no competencial.

En lo que se refiere a las tachas de orden competencial el recurso alega la infracción del art. 149.1.21 CE, que atribuye al Estado la competencia exclusiva sobre los transportes terrestres que transcurran por más de una comunidad autónoma.

Recuerda el TC que el arrendamiento de vehículos con conductor constituye una modalidad de transporte de viajeros y su ejercicio está condicionado a la obtención de una autorización que da derecho a prestar el servicio por todo el territorio nacional. Esta sería la razón que justificaría que tal autorización haya de ser expedida por el órgano competente de la Administración General del Estado en virtud del art. 149.1.21 CE.

No obstante lo anterior, el Estado, en virtud del procedimiento previsto en el art. 150.2 CE —a través de la Ley Orgánica 5/1987, de 30 de julio, de delegación de facultades del Estado en las Comunidades Autónomas en relación con los transportes por carretera y por cable-, delegó en las comunidades autónomas determinadas competencias en la materia. En la STC 105/2018, las partes discrepan sobre el alcance de lo delegado a las comunidades autónomas por el Estado en aquella norma.

25 Véanse supra pp. 19-20. 
Así, considera el recurrente que las facultades delegadas a las comunidades autónomas en la referida ley orgánica se circunscriben a los aspectos ejecutivos o de gestión en relación con las autorizaciones y no se extienden al establecimiento de normas. Por el contrario, consideran las instituciones autonómicas que la norma impugnada encuentra suficiente cobertura en las facultades delegadas a la comunidad autónoma de Cataluña mediante la citada ley orgánica.

El TC recuerda que la Ley Orgánica 5/1987 forma parte del bloque de la constitucionalidad en virtud de lo dispuesto en el art. 28 LOTC, cuando establece que para apreciar la conformidad o disconformidad con la Constitución de una ley, disposición o acto con fuerza de ley del Estado o de las comunidades autónomas el TC considerará, «además de los preceptos constitucionales, las Leyes que dentro del marco constitucional se hubieren dictado para delimitar las competencias del Estado y las diferentes Comunidades Autónomas o para regular o armonizar el ejercicio de las competencias de éstas», y entre las cuales se encuentran las leyes de delegación previstas en el art. $150.2 \mathrm{CE}$.

A continuación la STC 105/2018 se refiere a aquellos preceptos de la Ley $5 / 1987$, con las modificaciones posteriores correspondientes, que configuran el alcance de la referida delegación. Así se refiere al art. 5, en el que se enumeran las funciones que se delegan en las comunidades autónomas en razón del territorio en el que esté fijado el lugar de residencia del vehículo o esté situada la sede central de la empresa o la sucursal a la que va referida la autorización: a) el otorgamiento de las autorizaciones; b) la convalidación de la transmisión de las autorizaciones; c) su visado periódico; d) el establecimiento, en su caso, de tarifas; e) la revocación o condicionamiento de las autorizaciones; f) el establecimiento de prestación de servicios mínimos, y g) «cuantas actuaciones gestoras sean necesarias para el funcionamiento de los servicios y no se reserve para sí el Estado».

Considera el TC que ninguna de las concretas funciones o facultades enumeradas en el art. 5 de la Ley Orgánica 5/1987 incluye la competencia autonómica para dictar una norma que innove el régimen jurídico de las autorizaciones de transporte, en un aspecto tan relevante como es, en este caso, la prohibición temporal de transmisión de las autorizaciones.

La STC 105/2018 rechaza así que la función de «condicionamiento de las autorizaciones», que se ha delegado por el Estado en las comunidades autónomas, sirva como cobertura del precepto impugnado, pues considera que tal función delegada únicamente permite a las comunidades autónomas el establecimiento de cláusulas accesorias en el contenido de cada autorización, y no se puede confundir con una facultad para formular ex novo normas de 
carácter general, esto es, con una facultad normativa para fijar o completar su régimen jurídico.

En suma, para el TC la referida norma estatal no faculta a las comunidades autónomas para establecer normas adicionales sobre el régimen jurídico de las autorizaciones habilitantes para el arrendamiento de vehículos de turismo con conductor.

El TC afirma que el reciente Real Decreto Ley 13/2018 ha ampliado la delegación de competencias normativas de las comunidades autónomas que a partir de su entrada en vigor quedarían habilitadas para modificar aquellas concretas condiciones de explotación de las autorizaciones que el propio Real Decreto Ley identifica, «condiciones de servicio, precontratación, solicitud de servicios, captación de clientes, recorridos mínimos y máximos, servicios u horarios obligatorios y especificaciones técnicas». Sin embargo, para el TC la nueva habilitación normativa no incluye la capacidad de modificar el régimen jurídico de transmisión de las autorizaciones.

Dos consecuencias muy discutibles deben ser resaltadas de la anterior afirmación realizada por el TC. La primera, que el TC parece estar admitiendo que se produzca una ampliación de las competencias estatales en su día delegadas por una ley orgánica, pero esta vez a través de un decreto ley en lugar de a través de una nueva ley orgánica. Ciertamente el Decreto Ley 13/2018 afirma que las comunidades autónomas que por delegación del Estado sean competentes para otorgar autorizaciones de arrendamiento de vehículos con conductor de ámbito nacional quedan habilitadas para modificar las condiciones de explotación previstas en el art. 182.1 del Reglamento de la Ley de Ordenación de los Transportes Terrestres, en los términos que el propio decreto ley establece. Sin embargo, si las condiciones de explotación se encuentran reguladas en el art. 182.1 del Reglamento de la Ley de Ordenación de los Transportes Terrestres es porque el Estado tiene competencia sobre la materia ex art. 149.1.21 CE. Cualquier delegación/habilitación para modificar tales condiciones requiere una ley orgánica de las previstas en el art. 150.2 CE y no podría ser realizada a través de un decreto ley.

La segunda consecuencia es que el TC señala que la habilitación a las comunidades autónomas solo tiene eficacia a partir de la entrada en vigor de la norma que delega la competencia, sugiriendo así que en el supuesto de una eventual delegación de competencias a través del mecanismo previsto en el art. 150.2 CE no se sanaría un eventual ejercicio previo por parte de una comunidad autónoma de una competencia que hasta el momento de la delegación no tenía. Esto supondría un tratamiento diferenciado respecto de aquel otro supuesto en que una comunidad autónoma ve sobrevenidamente reconocida su competencia cuando se altera la normativa básica del Estado, 
pues en este supuesto el parámetro de control de acuerdo con la doctrina tradicional del TC es que la nueva norma básica sana un eventual ejercicio previo sin competencia por parte de una comunidad autónoma.

4. La STC 134/2018 (Pleno), de 13 de diciembre, resuelve el recurso de inconstitucionalidad interpuesto por el presidente del Gobierno contra la Ley 9/2017, de 3 de agosto, de regulación de las corridas de toros y de protección de los animales en las Illes Balears.

La impugnación se realiza por motivos puramente competenciales. Así, el Gobierno considera fundamentalmente que los siguientes preceptos de la norma autonómica menoscaban la competencia estatal para regular el patrimonio cultural español (art. 149.2 CE, en relación con el art. 149.1.28 CE): el art. 1.2, que solo permite la celebración de corridas de toros conforme a lo previsto en esa ley balear; art. 5.1, que establece el límite de edad de los toros para lidiar; art. 5.2, que establece el límite de peso de los toros para lidiar; art. 5.6, que regula las potestades de la presidencia de la plaza respecto de la celebración del espectáculo a la vista del acta veterinaria; art. 5.7, que determina las actuaciones que deben desarrollarse una vez finalizado el espectáculo; art. 6, que prohíbe el enchiqueramiento de los toros; art. 7, que prohíbe la presencia de caballos durante las corridas de toros; art. 8, que limita la posibilidad de participación en las corridas de toros a los profesionales inscritos en la sección I del registro general de profesionales taurinos - toreros y toreras, y su personal auxiliar - y establece que en las corridas el número de toros que se toreen será como máximo de tres con una participación no mayor a los diez minutos; art. 9, que prohíbe del uso de utensilios que puedan causar la muerte del animal o producirle heridas, y art. 15.3 b), que define como infracción muy grave la omisión de las medidas de protección y bienestar de los animales previstas en los arts. 8 y 9 .

Para abordar la impugnación el TC afirma remitirse a la doctrina recogida en la STC 177/2016, de 20 de octubre, que declaró la inconstitucionalidad de la Ley de Cataluña 8/2010, de 3 de diciembre, que prohibía las corridas de toros en aquella comunidad. Así, recuerda que el Estado, en ejercicio de su competencia en materia de cultura ex art. 149.2 CE, ha promulgado, mediante la Ley 18/2013, de 12 de noviembre, para la regulación de la Tauromaquia como patrimonio cultural, un mandato general a todos los poderes públicos en todo el territorio nacional para garantizar la conservación y promover el enriquecimiento de la tauromaquia.

Sin embargo, la STC 177/2016 ya señaló cómo el deber que aquella ley impone a los poderes públicos de garantizar la conservación y promover el enriquecimiento del patrimonio cultural (ex art. 46 CE y ex Ley 18/2013) no 
impone a estos la obligación de mantener de modo incondicional una interpretación que tienda al mantenimiento de todas las manifestaciones inherentes a los espectáculos tradicionales, como pueden ser las corridas de toros, sin tener en cuenta otros intereses y derechos protegidos que han de ser también adecuadamente ponderados.

La STC 177/2016 admitió así que una comunidad autónoma pudiese, en ejercicio de sus competencias sobre ordenación de espectáculos públicos, regular el desarrollo de las representaciones taurinas — limitando, por ejemplo, el acceso a las corridas a los mayores de catorce años o restringiendo sus celebraciones a las plazas ya construidas-; o que pudiese, en ejercicio de su competencia en materia de protección de animales, establecer requisitos para el especial cuidado y atención del toro bravo. Sin embargo, consideró que una medida prohibitiva como la que estableció Cataluña en su norma menoscababa por su propia naturaleza el ejercicio de una competencia concurrente del Estado (art. 149.2 CE) que responde también al mandato constitucional del art. $46 \mathrm{CE}$. En efecto, una prohibición general de las corridas de toros hace imposible la conservación de una tradición cultural que ha sido considerada digna de protección por el legislador estatal.

Así, si bien puede corresponder al legislador autonómico interpretar en el ejercicio de sus competencias sobre espectáculos públicos los deseos u opiniones que sobre las corridas de toros existen en la sociedad autonómica y establecer en su virtud una regulación específica y diferenciada de la regulación general, las diferencias que se establezcan no pueden llegar al extremo de impedir, perturbar o menoscabar el ejercicio legítimo de las competencias del Estado en materia de cultura al amparo del art. 149.2 CE.

La ley balear que se juzga en la STC 134/2018 no ha optado por una prohibición taxativa de las corridas de toros, pero el TC asume que se llega a una prohibición de facto de las corridas de toros, a través del establecimiento de prohibiciones y requisitos singulares que conducen a que la fiesta de los toros, tal y como se reconoce en Espańa y constituye parte de su patrimonio cultural, sea irrecognoscible. Así, según el TC, se produce una eliminación en el territorio autonómico balear de la corrida de toros moderna, al establecerse alteraciones cuantitativas y cualitativas que desvirtúan su recognoscibilidad como institución perteneciente al patrimonio cultural español. El TC acude en este punto el concepto de la garantía institucional para declarar la inconstitucionalidad de la norma balear. Utilización cuando menos discutible, pues supone utilizar una categoría con la que se persigue la protección frente al legislador de determinadas instituciones que se recogen en la Constitución para proteger la imagen maestra legalmente establecida por el Estado de una manifestación cultural. 
El TC realiza un examen de cada uno de los preceptos impugnados, si bien es la valoración conjunta de todos ellos la que determinará su conclusión de que la institución de la tauromaquia se convierta en una institución no reconocible y ajena a lo que constituye el patrimonio cultural en esta materia.

Así, constata el TC que los arts. 7 y 9 de la norma autonómica impugnada contienen una regulación que suprime el tercio de varas, el tercio de banderillas y la muerte del animal en el último tercio, lo que supone limitar el contenido de la corrida de toros al toreo con el capote y la faena de muleta. Para el TC, la regulación impugnada, en consecuencia, implica una importante innovación del desarrollo de la corrida de toros que la diferencia sustancialmente de la regulación contenida en la reglamentación taurina estatal y autonómica.

El TC admite el carácter consustancial a la corrida moderna de ciertas suertes o particularidades en el desarrollo de la lidia que se encuentran contenidas en una norma de carácter reglamentario (el reglamento taurino estatal), pero que son las que permiten un examen de la recognoscibilidad de la institución de la tauromaquia desde el punto de vista del reconocimiento social.

La argumentación de la STC 134/2018 es cuando menos discutible, y así se refleja en los tres votos particulares a la misma, uno concurrente, el del magistrado Ollero, y dos discrepantes, el de los magistrados Valdés y Balaguer y el del magistrado Xiol, que ya discreparon en la STC 177/2016. Entre las razones de la endeble fundamentación de la STC 134/2018 cabe señalar, en primer lugar, y como ya pusimos de manifiesto en la crónica en la que se examinó la doctrina de la STC 177/2016, que de la dicción del art. 149.2 CE se derivaría que la competencia de cultura sería una suerte de competencia compartida pero de carácter complementario, es decir, una competencia de fomento de la cultura, que tendría como límite la imposibilidad de armonizar las decisiones adoptadas por las comunidades autónomas. En segundo lugar, cabe discrepar del uso de la técnica de la garantía institucional fuera del ámbito de las instituciones reconocidas explícitamente en la Constitución. Y en tercer lugar, aún si se asumiese la técnica de la garantía institucional, no se alcanzan a vislumbrar las razones por las que algunos de los preceptos impugnados afectarían a la imagen maestra de la tauromaquia.

Así, en efecto, no cabe sino señalar la dificultad de poder compartir la argumentación al TC en el caso del examen del resto de preceptos impugnados. Por ejemplo, en relación con la previsión de restringir al número de tres las reses que pueden ser lidiadas en cada ocasión, el TC la declara inconstitucional por impedir o dificultar el normal desarrollo de las corridas de toros, y por no guardar relación con el número de reses que más frecuentemente son lidiadas en una corrida de acuerdo con la tradición. Parece así que el TC 
considera que la tauromaquia no es recognoscible como institución si son tres y no seis las reses lidiadas. Igualmente absurda es la argumentación en relación con el peso de los toros o en relación con el precepto que regula la manera en que deben de ser tratados y preparados los toros antes de proceder a su entrada en la plaza para la lidia que se declara inconstitucional "por suponer considerables dificultades, retrasos y alteraciones en el desarrollo del espectáculo incompatibles con su normal celebración en unas condiciones razonables de agilidad y continuidad». Así se subraya en el voto particular de los magistrados Valdés y Balaguer, donde se denuncia que el límite a la competencia autonómica, que la STC 177/2016 halló en la medida prohibitiva de la corrida de toros, alcanza ahora a medidas que se anulan por «impedir o dificultar el normal desarrollo de las corridas de toros» o por «alterar sustancialmente el desarrollo de la corrida de toros moderna».

5. La STC 137/2018 (Pleno), de 13 de diciembre, estima el recurso de inconstitucionalidad interpuesto por el presidente del Gobierno contra el art. 14.1 u) de la Ley de las Cortes de Aragón 10/2017, de 30 de noviembre, de régimen especial del municipio de Zaragoza como capital de Aragón.

La resolución llama la atención en primer lugar por la celeridad con la que se pronuncia el TC, pues se trata de un recurso interpuesto el 3 de agosto y resuelto el 13 de diciembre.

El TC considera que el precepto impugnado al sustraer al pleno municipal la facultad de determinar el órgano que debe asumir las funciones propias de la junta general de una sociedad mercantil cuyo capital pertenece íntegramente al municipio contraviene lo dispuesto por la normativa básica estatal en los arts. 85 ter.3 y $123.1 \mathrm{k}$ ) de la Ley 7/1985, de 25 de abril, de bases del régimen local (LBRL), en conexión con las normas sobre formación de la voluntad de los órganos colegiados en las sociedades mercantiles unipersonales.

El art. 14.1 u) de la Ley de Aragón 10/2017, al atribuir al Gobierno de Zaragoza «la formación de la voluntad del Ayuntamiento como socio único en las sociedades mercantiles cuyo capital social pertenezca íntegramente al municipio de Zaragoza, asumiendo las funciones de junta general», contradice lo dispuesto por el art. 85 ter.3 LBRL, al impedir que el pleno decida, al aprobar los estatutos de la sociedad, cuál es «la forma de designación y el funcionamiento de la junta general y del consejo de administración, así como los máximos órganos de dirección de las mismas».

Señala el TC que el legislador básico estatal ha reservado al pleno municipal la facultad de optar por una u otra fórmula organizativa en las sociedades mercantiles locales. La ley autonómica, al desapoderar al pleno de este ámbito de decisión, invade el espacio de autoorganización local garantizado 
por la normativa básica estatal, e incurre con ello en vulneración del art. 149.1.18 CE.

6. La STC 142/2018 (Pleno), de 20 de diciembre, estima parcialmente el recurso de inconstitucionalidad presentado por el Gobierno de la nación contra la Ley 15/2017, de 25 de julio, de la Agencia de Ciberseguridad de Cataluña.

La norma impugnada crea la Agencia de Ciberseguridad de Cataluña, a la que corresponde desarrollar y liderar el servicio público de ciberseguridad necesario para la protección del territorio de Cataluña, gestionar los incidentes de carácter global que afecten a Cataluña y a sus instituciones y coordinar los esfuerzos de los diferentes equipos que puedan tener conocimiento de ellos. La norma regula la naturaleza jurídica y el régimen que se aplica a la Agencia y define, entre otras cuestiones, su objeto y funciones, estructura orgánica, régimen económico y financiero, de contratación, de personal y de control y relaciones con el departamento de adscripción.

La STC 142/2018 desestima un primer motivo de impugnación fundado en que la creación de la Agencia es una estructura de Estado idónea para actuar de forma autónoma en un eventual Estado catalán independiente. El TC recuerda que las intenciones del legislador, su estrategia política o su propósito último no constituyen objeto de su enjuiciamiento, que ha de circunscribirse a contrastar los concretos preceptos impugnados y las normas y principios constitucionales que integran en cada caso el parámetro de control.

Sin embargo, la STC 142/2018 estima parcialmente un segundo motivo de impugnación que se funda en una vulneración competencial.

Así, en un primer momento el TC conceptúa la ciberseguridad como aquel conjunto de mecanismos dirigidos a la protección de las infraestructuras informáticas y de la información digital que albergan que presenta un componente tuitivo y que se proyecta específicamente sobre el concreto ámbito de la protección de las redes y sistemas de información que utilizan los ciudadanos, empresas y Administraciones públicas. El TC recuerda que el uso cotidiano de las tecnologías de la información y la comunicación las ha convertido en un elemento esencial para el desarrollo económico y las relaciones sociales.

Considera el TC que la ciberseguridad no es un concepto o materia reconducible a un único título competencial. Puede identificarse con la seguridad nacional o con la seguridad pública cuando se trata de la protección ordinaria de las redes y las infraestructuras de telecomunicaciones, en cuyo caso es reconducible a los títulos competenciales exclusivos del Estado en materia de seguridad pública (art. 149.1.29 CE), en materia de defensa (art. 149.1.4 CE) y en materia de telecomunicaciones (art. 149.1.21 CE). Pero 
también puede proyectarse sobre otros planos, como es el caso de la Administración electrónica, que abarca la organización de medios y previsión de medidas de protección de la Administración y, por extensión, la protección de los derechos de los ciudadanos cuando se relacionan con la Administración por medios electrónicos, en cuyo caso es reconducible a los títulos competenciales autonómicos que se le reconocen estatutariamente y que permitirían a una Administración autonómica adoptar determinadas medidas dirigidas a garantizar la protección de sus infraestructuras y la seguridad de las tecnologías de la información y la comunicación.

De acuerdo con ello, la Generalitat puede adoptar medidas en materia de ciberseguridad en tanto en cuanto se aplican a las relaciones que tiene con sus administrados y con otras Administraciones, así como respecto de las infraestructuras tecnológicas, que pertenezcan a la estructura de la Administración de la Generalitat y a su sector público.

Por tanto, el elemento esencial para determinar la constitucionalidad o inconstitucionalidad de la regulación autonómica es la determinación de cuáles de los preceptos impugnados han pretendido regular la ciberseguridad como un ámbito material relacionado con la seguridad pública, y cuáles persiguen dar una respuesta a las amenazas que puedan afectar a las redes de comunicación electrónica y sistemas de información de las Administraciones públicas de Cataluña. Con base en la diferencia referida, la STC 142/2018 va resolviendo la impugnación de los diferentes preceptos de la ley autonómica,

Así, por ejemplo, la STC 142/2018 declara inconstitucional y nulo el art. 2.1 cuando prescribe que «la Agencia de Ciberseguridad de Cataluña tiene por objeto garantizar la ciberseguridad en el territorio de Cataluña, entendida como la seguridad de las redes de comunicaciones electrónicas y de los sistemas de información", pues considera que las competencias autonómicas no permiten amparar la pretensión de configurar una garantía general y omnicomprensiva de la ciberseguridad.

Igualmente declara inconstitucional y nulo el art. 2.3 cuando establece que la Agencia puede ejercer sus funciones «con relación a las personas físicas o jurídicas situadas en Cataluña», pues considera que no se limita a objetivos relacionados con la necesidad de proteger las redes y sistemas de información propios y los de los particulares y de otras Administraciones que se relacionan por medios electrónicos con la Administración.

La ciberseguridad como tal garantía se integra en las competencias estatales en materia de seguridad pública y de telecomunicaciones, y la atribución incondicionada a la Agencia de una garantía general en el territorio de Cataluña desborda los márgenes en los que la ciberseguridad se puede incluir en las competencias autonómicas, pues tales márgenes se refieren exclusivamente a 
las actuaciones de la Administración de la Generalitat y su sector público en relación con la protección de sus sistemas de información y comunicación.

En esta línea, la STC 142/2018 considera, sin embargo, que cabe realizar una interpretación constitucional del art. 2.2, en el que se define el objetivo de la Agencia como «la ejecución de las políticas públicas en materia de ciberseguridad», añadiendo a continuación que, en particular, ese objetivo se concreta en las actuaciones que se enumeran en los cinco subapartados, relativos a asesorar al Gobierno y prestarle apoyo en la elaboración de los planes de ciberseguridad; ejecutar los planes de ciberseguridad; coordinarse con otros organismos en el desarrollo de estos planes; organizar actividades de difusión, formación y concienciación dirigidas a los diferentes colectivos de destinatarios, haciendo especial énfasis en las situaciones de vulnerabilidad y facilitando instrumentos y programas al respecto, e impulsar un clima de confianza y seguridad que contribuya al desarrollo de la economía y de la sociedad digital en Cataluña.

Para el TC el precepto referido, si se interpreta en el sentido de que el objetivo que persigue la Agencia se relaciona con la necesidad de proteger las redes y sistemas de información de la Administración de la Generalitat y de su sector público y los de los particulares y otras Administraciones públicas que se relacionan por medios electrónicos con dicha Administración, no es contrario al orden constitucional de distribución de competencias. Esta interpretación es llevada al fallo ${ }^{26}$.

\section{ORGANIZACIÓN DE LOS PODERES PÚBLICOS}

1. En la crónica correspondiente al primer cuatrimestre de 2018 dábamos cuenta de las SSTC 34/2018 (Pleno), de 12 de abril, y 44/2018 (Pleno), de 26 de abril ${ }^{27}$, que resolvieron sendos conflictos de órganos constitucionales trabados entre el Gobierno y la Mesa del Congreso de los Diputados en torno al alcance del veto presupuestario del Gobierno previsto en el art. 134.6 CE. Recordábamos entonces que si hasta la fecha el TC solo había tenido que resolver dos conflictos entre órganos constitucionales del Estado (STC 45/1986, de 17 de abril, y 234/2000, de 3 de octubre), la compleja situación política derivada del desgaste del sistema bipartidista ha propiciado la presentación de nuevos conflictos, de los que el TC ha resuelto dos en un mismo mes en las citadas sentencias, siendo previsible que dictase pronto una tercera, esta

26 Tomás de la Quadra Salcedo.

27 Reseñadas en $R E D C$, núm. 113, 2018, pp. 233-234 y 261-264. 
vez en relación con el problema de la negativa del Gobierno en funciones a someterse al control parlamentario. Así ha ocurrido en efecto con la aprobación de la STC 124/2018 (Pleno), de 17 de septiembre, a la que luego nos referiremos.

Por otra parte, la doctrina sentada en las SSTC 34/2018 y 44/2018 en relación con el veto presupuestario del Gobierno a la tramitación de iniciativas legislativas que impliquen aumento de créditos o disminución de ingresos presupuestarios (art. 134.6 CE) se proyecta, durante el período considerado en la presente crónica, en sendos recursos de amparo parlamentario, resueltos por las SSTC 94/2018 (Sala Segunda), de 17 de septiembre, y 139/2018 (Sala Primera), de 17 de diciembre.

La STC 94/2018 ${ }^{28}$ estima el recurso de amparo parlamentario interpuesto contra los acuerdos de la Mesa del Congreso de los Diputados que, con aceptación del criterio del Gobierno, resolvieron la no procedencia de someter a toma en consideración por el Pleno del Congreso la proposición de ley para el cierre de las centrales nucleares presentada por el grupo parlamentario que formula el recurso. Considera la STC 94/2018 que los acuerdos impugnados han vulnerado el derecho de participación política de los diputados recurrentes, porque la aplicación de la facultad de veto del Gobierno, asumida por el órgano parlamentario, se ha fundamentado en una argumentación contraria al sentido y alcance del art. 134.6 CE, en cuanto que ha considerado que el presupuesto habilitante de la misma (aumento de los créditos o disminución de los ingresos) debía extenderse a escenarios presupuestarios plurianuales, cuando es lo cierto que aquella únicamente puede venir referida a las partidas de gastos y previsión de ingresos presupuestarios que hayan sido previamente aprobadas por las Cortes en la ley anual de presupuestos generales del Estado y se refieran al presupuesto en vigor o al que lo esté en situación de prórroga, de conformidad con la doctrina sentada en las SSTC 34/2018 y 44/2018 (FJ 7).

A su vez, la STC 139/2018 ${ }^{29}$ estima el recurso de amparo parlamentario interpuesto contra los acuerdos de la Mesa del Congreso de los Diputados que, con aceptación del criterio del Gobierno, resolvieron la no procedencia de someter a toma en consideración por el Pleno del Congreso una proposición de ley en materia de pensiones no contributivas de la Seguridad Social presentada por el grupo parlamentario que formula el recurso. Estima la STC 139/2018 que los acuerdos impugnados han vulnerado el derecho de participación política de los diputados recurrentes, porque la aplicación de la facultad de veto del Gobierno, asumida por el Congreso, se sustenta sobre

28 Véanse pp. 257 y 293-295.

29 Véase supra p. 257. 
apreciaciones hipotéticas, sin contrastar el impacto real y efectivo de la iniciativa legislativa propuesta sobre los presupuestos generales del Estado vigentes, como exige la doctrina establecida en las SSTC 34/2018 y 44/2018 (FF. JJ. 6 y 7 ).

2. La STC 124/2018 (Pleno), de 17 de septiembre ${ }^{30}$, resuelve, como se ha indicado, el conflicto suscitado por la negativa del Gobierno en funciones a someterse a iniciativas de control del Congreso de los Diputados, en la medida en que no existe una relación de confianza entre el Gobierno y la Cámara en el caso de investidura fallida del presidente del Gobierno, como sucedió tras las elecciones generales de 20 de diciembre de 2015.

El TC recuerda que el interés que ha de ser preservado en el proceso para la resolución de conflictos entre órganos constitucionales del Estado es estrictamente el del respeto a la pluralidad o complejidad de la estructura de poderes constitucionales, lo que tradicionalmente se ha llamado «división de poderes» (STC 124/2018, FJ 5). La forma parlamentaria de gobierno («parlamentarismo racionalizado») de nuestro modelo constitucional (art. 1 CE) implica un sistema de distribución de poderes que, sin perjuicio de la posición de preeminencia de las Cortes Generales como depositarias de la soberanía (arts. 1.2 y $66 \mathrm{CE}$ ), evita su concentración y hace posible la aplicación de las técnicas de relación y control entre quienes lo ejercen legítimamente. Las formas de gobierno parlamentario se basan en la existencia de una relación de confianza entre el Gobierno y las Cámaras y, concretamente, en nuestra Constitución, en la relación fiduciaria que ha de existir entre el Gobierno y el Congreso de los Diputados. Tras la celebración de las elecciones, esa relación de confianza no se inicia hasta que el Congreso de los Diputados, conforme a lo dispuesto en el art. $99 \mathrm{CE}$, elige al presidente del Gobierno. Ahora bien, lo que no se infiere de nuestra Constitución es una pretendida identificación plena de función de control y relación de confianza entre Gobierno y Congreso de los Diputados (FJ 6).

La función de controlar la acción del Gobierno es consustancial a la forma de gobierno parlamentario, se asienta en la legitimidad democrática y en el carácter representativo de las Cortes Generales y no deriva de la relación de confianza con el Gobierno, y debe diferenciarse entre función de control y relación de confianza (que comporta la exigencia de responsabilidad política), por más que tampoco pueda negarse que ambos conceptos están estrechamente relacionados. La relación de confianza se predica exclusivamente del Congreso (art. $108 \mathrm{CE}$ ), mientras que la función de control se atribuye a las

30 Véanse supra pp. 255-256. 
Cortes Generales (art. 66.2 CE), lo que comporta que también el Senado pueda ejercerla, pese a que no exista relación fiduciaria entre esta Cámara y el Gobierno. La función de control, en suma, se ejerce por ambas Cámaras a través de los instrumentos del título $\mathrm{V}$ de la Constitución; de los allí contemplados, los previstos en los arts. 109, 110 y $111 \mathrm{CE}$ corresponden a ambas Cámaras, mientras que la moción de censura y la cuestión de confianza (instrumentos de control estos que pueden determinar la ruptura de la relación de confianza), solo al Congreso (FJ 7).

El Gobierno en funciones (art. 101.2 CE) no puede quedar exento del control de las Cortes Generales (art. 66.2 CE), ya que con ello se afectaría al equilibrio de poderes previsto en la Constitución, además de que el menoscabo de la función de control podría implicar una limitación del derecho a ejercer la función parlamentaria y, con él, del derecho de participación ciudadana (art. $23 \mathrm{CE}$ ). De modo que «la cuestión no es si el Gobierno en funciones está sometido al control del Parlamento, que lo está, sino en el alcance de dicho control». En la medida en que el Gobierno en funciones sigue desarrollando actividad, esta no puede quedar exenta del control de las Cámaras, sin perjuicio de que ese control «habrá de adecuarse a la propia situación del Gobierno en funciones» $\mathrm{y}$ "ejercerse de acuerdo con el principio de lealtad institucional que ha de presidir las relaciones entre órganos constitucionales» (FF. JJ. 8 y 9$)^{31}$.

\section{DERECHOS FUNDAMENTALES}

1. En la STC 111/2018, (Pleno), de 17 de octubre ${ }^{32}$, el recurso de amparo afirmaba que la decisión del Instituto Nacional de la Seguridad Social - confirmada en la vía judicial - de no conceder al demandante el derecho a disfrutar la prestación económica por paternidad con la misma duración que la establecida para el permiso por maternidad constituía un trato desigual carente de justificación razonable y proporcionada, que lesionaba el art. 14 CE. Advierte el TC en la sentencia que el planteamiento de la demanda de amparo encubría la pretensión de que los órganos judiciales $-\mathrm{y}$ antes la entidad gestora de la Seguridad Social - hubieran dejado de aplicar las normas legales vigentes a la fecha del hecho causante, que establecían un permiso de paternidad de trece días y la correlativa prestación económica de la Seguridad Social. El problema reside, por tanto, en dilucidar si esa normativa, aplicada

31 Herminio Losada González.

32 Véase supra p. 258. 
en las resoluciones impugnadas, es conforme al derecho fundamental garantizado por el art. $14 \mathrm{CE}$, como entendieron los órganos judiciales. Recuerda el TC que el principio de igualdad no exige en todos los casos un tratamiento legal igual con abstracción de cualquier elemento diferenciador de relevancia jurídica, de manera que no toda desigualdad de trato normativo respecto a la regulación de una determinada materia supone una infracción del art. $14 \mathrm{CE}$, sino tan solo las que introduzcan una diferencia entre situaciones que puedan considerarse iguales, sin que exista una justificación objetiva y razonable para ello. El recurso de amparo traía causa de un proceso especial en materia de seguridad social en el que se discutía el pretendido derecho de un padre biológico, trabajador por cuenta ajena, a percibir el subsidio por paternidad con la misma extensión y duración que la establecida legalmente para el subsidio por maternidad. Considera el TC que se desprende de la normativa aplicada que la finalidad que persigue el legislador en la protección laboral y de seguridad social dispensada en el supuesto de parto es diferente en atención a que se trate de la madre o del padre. En el caso de la madre, la «finalidad primordial» que persigue desde siempre el legislador al establecer el descanso por maternidad y el correspondiente subsidio económico de la Seguridad Social es la protección de la salud de la mujer trabajadora, durante el embarazo, parto y puerperio. Este descanso es obligatorio como mínimo en las seis semanas inmediatamente siguientes al alumbramiento; por eso el legislador, cuando permite a la madre ceder al padre, cuando ambos trabajen, una parte determinada de su período de descanso por maternidad, excluye en todo caso la parte de descanso obligatorio posparto, que resulta así indisponible para la madre. Distintos son el permiso por paternidad y la correlativa prestación que se reconocen en nuestro ordenamiento social a partir de 2007 a los padres; inicialmente con una duración de trece días, que fue la disfrutada por el recurrente en amparo, y sucesivamente ampliada a cuatro semanas y luego a cinco semanas. Tienen, como es obvio, una finalidad distinta, que no es otra que la de favorecer la conciliación de la vida personal, familiar y laboral, fomentando la corresponsabilidad de madres y padres en el cuidado de los hijos. De ahí la diferencia de trato entre hombres y mujeres — padres y madres- que establece la legislación laboral y de seguridad social, tanto la aplicada en su día al recurrente en amparo como la actualmente vigente, en relación con los permisos de maternidad y de paternidad en el supuesto de parto: derecho a suspender el contrato de trabajo y a percibir los correspondientes subsidios de la Seguridad Social. En definitiva, descarta el TC que esa diferencia de trato en cuanto a la duración de los permisos y prestaciones incurra en vulneración del principio de igualdad ante la ley, pues se trata de situaciones diferentes en la consideración de la finalidad tuitiva perseguida por el legislador, por lo que no 
concurre siquiera un término de comparación adecuado. En similares términos las SSTC 117/2018 (Sala Primera), de 29 de octubre, y 138/2018 (Sala Segunda), de 17 de diciembre.

2. En la STC 91/2018 (Sala Primera), de 17 de septiembre ${ }^{33}$, el objeto era determinar si las resoluciones judiciales impugnadas habían vulnerado el derecho a la libertad personal (art. 17.1 CE) de los demandantes de amparo por haberse acordado su prisión provisional incondicional conjuntamente con la notificación de la sentencia condenatoria de instancia a una pena de seis ańos de prisión, pero sin convocar la comparecencia prevista en el art. 505 de la Ley de Enjuiciamiento Criminal (LECrim) dentro del plazo de las 72 horas que señala el art. 539 LECrim. Recuerda el TC que la jurisprudencia constitucional, en el específico marco de la medida cautelar de prisión provisional, ha establecido que la exigencia general de habilitación legal supone que la decisión judicial de decretar, mantener o prorrogar la prisión provisional ha de estar prevista en uno de los supuestos legales y que ha de adoptarse mediante el procedimiento legalmente regulado. En concreto, por lo que se refiere a la existencia de una audiencia previa - o inmediata posterior en caso de urgencia- en la que se sustancie la pretensión de las acusaciones de que se adopten o agraven las medidas cautelares privativas de libertad, la jurisprudencia constitucional considera que si esa audiencia está expresa y claramente prevista en la ley para la adopción de la decisión controvertida es un requisito procedimental que queda integrado en la exigencia del art. 17.1 CE, por lo que su omisión constituye una vulneración de dicho artículo. En el caso analizado considera acreditado el TC que el órgano judicial, mediante sendos autos, adoptó la decisión de modificar la previa situación de libertad que tenían los recurrentes por la de prisión provisional incondicional de manera simultánea al dictado de la sentencia condenatoria en primera instancia al considerar que concurría un elevado e inminente riesgo de fuga, invocando para ello el art. 539 LECrim con el argumento de que este precepto establece «que los autos de prisión y libertad provisionales son reformables durante el curso de la causa, añadiendo que, si a juicio del juez, hubiere riesgo de fuga de quien se encontrare en libertad procederá a dictar auto de reforma de la medida cautelar». No convocó, sin embargo, la comparecencia prevista en el art. 505 LECrim para su celebración en el plazo de 72 horas desde la adopción de esta medida cautelar. El órgano judicial denegó la petición efectuada por los demandantes de amparo para la celebración de dicha comparecencia, argumentando que «la comparecencia prevista en el artículo 505 de la Ley de

33 Véanse supra pp. 257 y 259. 
Enjuiciamiento Criminal, como trámite previo a acordar la prisión provisional de un individuo no resulta aplicable a los supuestos de condena impuesta en sentencia, pues ésta constituye "título ejecutivo" que habilita al tribunal sentenciador a acordar su inmediata efectividad cuando se detecte un elevado riesgo de fuga». Los «casos» y la «forma» en que la ley española regulaba en el momento en que se dictaron las resoluciones impugnadas la reforma peyorativa de la situación personal de quien está sometido a procedimiento mediante la adopción de una medida cautelar privativa de libertad aparecen establecidos en el art. 539 LECrim, en la redacción dada a sus dos primeros párrafos y el quinto por la Ley Orgánica 5/1995, de 22 de mayo, y, en sus párrafos tercero

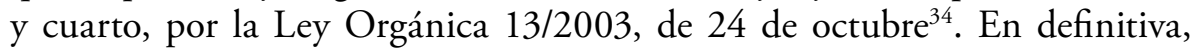
constata el TC que la garantía procedimental con que la ley, en desarrollo de lo previsto en el art. 17.1 CE, ha revestido a la decisión judicial urgente del dictado del auto de reforma de la medida cautelar, o incluso de prisión si el imputado se encontrase en libertad, es la de convocar, para dentro de las 72 horas siguientes, la comparecencia del art. 505 LECrim. Por otra parte, considera que, en virtud del art. 861 bis.a) LECrim ${ }^{35}$, en nuestro sistema de justicia penal la condena en primera instancia no permite todavía la ejecución de las penas impuestas, sin perjuicio de que puedan adoptarse las medidas

34 Que dispone: «Los autos de prisión y libertad provisionales y de fianza serán reformables durante todo el curso de la causa. En su consecuencia, el imputado podrá ser preso y puesto en libertad cuantas veces sea procedente, y la fianza podrá ser modificada en lo que resulte necesario para asegurar las consecuencias del juicio. Para acordar la prisión o la libertad provisional con fianza de quien estuviere en libertad o agravar las condiciones de la libertad provisional ya acordada sustituyéndola por la de prisión o libertad provisional con fianza, se requerirá solicitud del Ministerio Fiscal o de alguna parte acusadora, resolviéndose previa celebración de la comparecencia a que se refiere el artículo 505. No obstante, si a juicio del juez o tribunal concurrieren los presupuestos del artículo 503, procederá a dictar auto de reforma de la medida cautelar, o incluso de prisión, si el imputado se encontrase en libertad, pero debiendo convocar, para dentro de las 72 horas siguientes, a la indicada comparecencia. Siempre que el Juez o Tribunal entienda que procede la libertad o la modificación de la libertad provisional en términos más favorables al sometido a la medida, podrá acordarla, en cualquier momento, de oficio y sin someterse a la petición de parte».

35 Que establece que "[l]as sentencias contra las cuales pueda interponerse recurso de casación no se ejecutarán hasta que transcurra el término señalado para prepararlo», y si se prepara este se «acordará en la misma resolución que continúe o se modifique la situación del reo o reos»; añadiendo el art. 861 bis.b) LECrim que «[c]uando el recurso hubiere sido preparado por uno de los procesados, podrá llevarse a efecto la sentencia desde luego en cuanto a los demás, sin perjuicio de lo dispuesto en el artículo 903». 
cautelares de naturaleza personal que se consideren convenientes para no frustrar una eventual ejecución futura. En atención a lo expuesto, afirma el TC que la decisión judicial impugnada de considerar innecesaria la celebración sobrevenida de una audiencia con el objeto de poder someter a debate la concurrencia de los presupuestos necesarios para acordar la medida de prisión provisional revirtiendo la situación de libertad de la que gozaban hasta el momento de su condena los recurrentes ha vulnerado su derecho a la libertad personal. En similares términos, la STC 92/2018 (Sala Primera), de 17 de septiembre.

3. En la STC 133/2018, (Pleno), de 13 de diciembre ${ }^{36}$, se impugnaban las conclusiones del dictamen de la comisión especial de investigación de las Cortes Valencianas sobre el accidente de la línea 1 del metro de Valencia ocurrido el 3 de julio de 2006, en cuanto en ellas se declaraba al recurrente responsable de dicho accidente, entre otras personas, en el ámbito de la empresa pública FGV (Ferrocarriles de la Generalitat Valenciana), de la que entonces era director de recursos humanos, «por falta de cumplimiento de la Ley de prevención de riesgos laborales». El recurrente en amparo entendía que una comisión parlamentaria de investigación debe limitarse a establecer la responsabilidad política de los titulares del poder público concernidos por el asunto investigado, pero que no puede declarar la responsabilidad jurídica de todas las personas relacionadas con los hechos que se investigan. En este caso, entendía que se habría vulnerado su derecho a la tutela judicial efectiva, con indefensión, en relación con el derecho a un proceso con todas las garantías, y su derecho a la presunción de inocencia, pues esta declaración de responsabilidad se ha llevado a cabo al margen de los procedimientos legalmente establecidos. Asimismo, estimaba que la referida declaración lesionó también su derecho al honor (art. 18.1 CE), en la medida en que la publicación de su nombre como responsable del accidente supone un ataque a su reputación personal y profesional. En primer lugar, el TC subsume la denunciada violación de los derechos a la tutela judicial efectiva y a un proceso con todas las garantías en la aducida lesión del derecho a la presunción de inocencia, en su dimensión extraprocesal. Recuerda que el derecho a la presunción de inocencia opera en las situaciones extraprocesales y constituye el derecho a recibir la consideración y el trato de no autor o no partícipe en hechos de carácter delictivo o análogo a estos, sin previa resolución dictada por el poder público u órgano competente que así lo declare. El TC ha considerado que la dimensión extraprocesal de la presunción de inocencia, reconocida también por el TEDH,

36 Véanse supra pp. 258 y 260-261. 
encuentra específica protección en nuestro sistema de derechos fundamentales a través de la tutela del derecho al honor. Recuerda que el derecho al honor protege frente a aquellas críticas o informaciones acerca de la conducta profesional o laboral de una persona que puedan constituir un auténtico ataque a su honor personal. Analizado el marco normativo regulador de la actividad investigadora de las Cortes Valencianas ${ }^{37}$, subraya que en la demanda de amparo se centra, exclusivamente, en la conclusión aprobada por el Pleno de las Cortes Valencianas, a propuesta de la comisión de investigación, que le declara responsable del accidente investigado «por falta de cumplimiento de la Ley de prevención de riesgos laborales». Destaca el TC que la actividad parlamentaria de investigación es una actividad de naturaleza estrictamente política, que en modo alguno puede ser reputada o calificada como jurisdiccional; tampoco las Cámaras son titulares en el ejercicio de esta actividad de la otra manifestación del ius puniendi del Estado, cual es la potestad administrativa sancionadora. En consonancia con su naturaleza política, las Cámaras, en el ejercicio de sus facultades de investigación, «emiten, como les es propio, juicios de oportunidad política que, por muy sólidos y fundados que resulten, carecen jurídicamente de idoneidad para suplir la convicción de certeza que sólo el proceso judicial garantiza»; así pues, sus decisiones, adoptadas libremente, responden a una valoración con arreglo a criterios políticos o de oportunidad de los hechos investigados y de las actuaciones de los sujetos responsables y carecen de efectos jurídicos y no son vinculantes para los tribunales ni afectan a las resoluciones judiciales. Por tanto, en atención a su naturaleza es evidente que excede del marco propio de la actividad investigadora parlamentaria no solo cualquier posible calificación jurídica de eventuales actos o conductas punibles, sino también su imputación o atribución

37 En el ejercicio de la función investigadora que le atribuye el Estatuto de Autonomía de la Comunidad Valenciana, el Pleno de las Cortes Valencianas acordó crear la comisión especial de investigación sobre el accidente de la línea 1 de Metrovalencia. El objetivo principal de la comisión era «determinar las responsabilidades políticas en que se pudiera haber incurrido desde la administración autonómica valenciana y la empresa FGV en la gestión de los hechos objeto de investigación», y se debían investigar "tanto el accidente como la gestión que posteriormente se hizo de él»y establecerse "las responsabilidades en los ámbitos profesional, técnico, de gestión y político que se determinen en las investigaciones». Se definía también como objetivo fundamental de la comisión «ofrecer una explicación convincente a la ciudadanía de lo ocurrido en toda su extensión y dimensión", tarea que había de ser complementada con otra, que se calificaba de esencial, que consistía en "proponer mecanismos e instrumentos para que las irregularidades y presuntas ilegalidades encontradas no vuelvan a ocurrir» (BOCV, núm. 104, de 19 de agosto, pp. 1322-13123). 
individualizada a los sujetos a los que pudiera alcanzar la investigación. En la conclusión de la comisión, la Cámara viene a reprocharle el incumplimiento de una determina normativa legal, que es lo mismo que la atribución, aunque sin concretar su calificación jurídica, de conductas punibles en el ámbito de la actividad profesional del demandante, que bien pudieran ser constitutivas de ilícitos administrativos en el orden social o, incluso, de ilícitos de carácter penal. Concluye el TC que una imputación en los términos aseverativos que se formula como la que se recoge en la conclusión de la actividad investigadora parlamentaria recurrida en amparo excede del ámbito propio de una actividad de ese tipo, pues a las Cámaras no les corresponde declarar la existencia de conductas punibles y la determinación de su autoría. Matiza el TC que lo relevante no es esa extralimitación de la Cámara en el ejercicio de su actividad investigadora, sino que la conclusión aprobada en la que se viene a imputar al recurrente la autoría de ilícitos bien administrativos bien penales resulta lesiva de su derecho al honor. Derecho que se ve afrentado cuando, sin intervención de los órganos constitucionalmente competentes y a través de los procedimientos legalmente previstos, un poder público atribuye a una persona conductas merecedoras del máximo reproche social, pues este derecho fundamental ampara la buena reputación de una persona "protegiéndola frente a expresiones o mensajes que la hagan desmerecer en la consideración ajena al ir en su descrédito o menosprecio o sean tenidas en el concepto público por afrentosas».

4. En la STC 94/2018 (Sala Segunda), de 17 de septiembre ${ }^{38}$, el portavoz del Grupo Unidos-Podemos impugnaba en amparo los acuerdos de la Mesa del Congreso de los Diputados que desestimaron la solicitud de toma en consideración por el Pleno del Congreso de los Diputados de la «Proposición de Ley para el cierre de las centrales nucleares», que el precitado grupo parlamentario había presentado ante aquel órgano parlamentario. Planteaba la eventual vulneración del derecho de participación del art. 23.2 CE, porque entendía que los acuerdos impugnados han dado la conformidad de la Mesa del Congreso a la aplicación, por parte del Gobierno, de la facultad de veto a las iniciativas legislativas parlamentarias que el art. 134.6 CE le reconoce a este, permitiendo de este modo que dicho ejercicio se haya extendido a un ámbito no previsto por el precepto constitucional, dado que dicha potestad tiene como límite temporal el del ejercicio presupuestario en vigor y no cuando la proposición de ley pueda afectar a ejercicios presupuestarios futuros, para los que no ha sido aprobado todavía el presupuesto anual correspondiente. Se remite el

38 Véanse supra pp. 257 y 285. 
TC en lo que se refiere al alcance y contenido de la denominada «facultad de veto» del art. $134 \mathrm{CE}$ a sus SSTC 34, de 12 de abril, y 44/2018, de 26 de abril ${ }^{39}$. Recuerda que corresponde en exclusiva al Gobierno la iniciativa parlamentaria en materia presupuestaria mediante el proyecto de ley anual de presupuestos, así como la ejecución del presupuesto aprobado y las posibles modificaciones. En lo que se refiere a la facultad de «veto» que el art. 134.6 $\mathrm{CE}$ atribuye al Gobierno, destaca que la propia literalidad del precepto constitucional "ciñe dicha potestad del Gobierno a los ingresos y gastos que estén efectivamente reflejados en el mismo presupuesto». En lo que se refiere al alcance temporal del veto presupuestario, «la conformidad del Gobierno ha de referirse siempre al presupuesto en vigor en cada momento, en coherencia con el propio principio de anualidad contenido en el mismo artículo». Respecto de la motivación el TC ha declarado que

[...] el Gobierno podrá oponerse sólo en aquellos casos en los cuales la medida propuesta, enmienda o proposición, incida directamente en el citado presupuesto. Dispondrá el Gobierno de un amplio margen de apreciación para hacer uso de esta facultad, pero deberá precisar adecuadamente los concretos créditos que se verían directamente afectados, de entre los contenidos en el presupuesto en vigor, habida cuenta que es éste el que cumple en cada momento su función instrumental a la propia acción de Gobierno (art. $97 \mathrm{CE}$ ).

Al analizar el fondo del asunto, partiendo del marco constitucional y normativo parlamentario ${ }^{40}$, constata el TC que el acuerdo que resuelve la solicitud de reconsideración formulada por el Grupo Parlamentario Unidos-Podemos incluye ya una argumentación que, en forma de resultandos y considerandos, contiene una respuesta a las alegaciones de aquel. La denuncia del recurrente se encamina a la censura de la falta de control material en la que

39 Reseñadas en $R E D C$, núm. 113, 2018, pp. 233-234 y 261-262.

40 Art 134.6 CE: «Toda proposición o enmienda que suponga aumento de los créditos o disminución de los ingresos presupuestarios requerirá la conformidad del Gobierno para su tramitación».

Art. 126 RCD: «2. Ejercitada la iniciativa, la Mesa del Congreso ordenará la publicación de la proposición de ley y su remisión al Gobierno para que manifieste su criterio respecto a la toma en consideración, así como su conformidad o no a la tramitación si implicara aumento de los créditos o disminución de los ingresos presupuestarios. 3. Transcurridos treinta días sin que el Gobierno hubiera negado expresamente su conformidad a la tramitación, la proposición de ley quedará en condiciones de ser incluida en el orden del día del Pleno para su toma en consideración». 
habría incurrido la resolución de la Mesa, pues se habría limitado a aceptar la decisión gubernamental, mediante una mera remisión a los argumentos sostenidos por el Gobierno, para vetar la tramitación de la proposición de ley presentada. La objeción más importante que formula el recurrente es que se ha extendido el ámbito temporal del ejercicio de la facultad de veto del art. 134.6 CE, más allá del presupuesto en curso, pretextando que, por su vinculación al principio de estabilidad presupuestaria la limitación contenida en el art. 134.6 CE ha de entenderse también aplicable a estos ejercicios presupuestarios posteriores, esto es, a los denominados «escenarios presupuestarios plurianuales», para de ese modo tratar de responder al alegato de que la proposición de ley presentada demoraría el impacto en las cuentas públicas a los años siguientes a los del presupuesto en vigor, en la medida en que el cierre de las centrales nucleares a que hace referencia la proposición de ley figura programado para ejercicios venideros. El argumento así expuesto, asumido por el acuerdo impugnado, contraviene la doctrina del TC, que, con claridad, ha delimitado el ámbito temporal de la aplicación de la potestad gubernamental de referencia, que lo circunscribe al ejercicio presupuestario en curso. La decisión de la Mesa, concluye el TC, conlleva una doble consecuencia desfavorable: de una parte, desnaturaliza la propia razón de ser de la potestad de veto del Gobierno del art. 134.6 CE, y, de otro lado, ocasiona una limitación que es contraria a los derechos del art. $23 \mathrm{CE}$ del recurrente. En sentido similar, la STC 139/2018 (Sala Primera), de 17 de diciembre.

En la STC 125/2018, (Sala Segunda), de 26 de noviembre ${ }^{41}$, la recurrente impugnaba la sentencia dictada por la Sala de lo Social del Tribunal Superior de Justicia de Andalucía, que desestimó el recurso de suplicación interpuesto frente a la sentencia dictada por el Juzgado de lo Social en procedimiento de despido. La recurrente imputaba a ambas resoluciones judiciales la vulneración de su derecho fundamental de participación política (art. 23 $\mathrm{CE}$ ), ya que, en su opinión, el despido debió declararse nulo. Razona en su demanda que el cómputo como absentismo de las horas invertidas en asistencia a plenos municipales y comisiones informativas supone una consecuencia desfavorable exclusivamente derivada del legítimo ejercicio de su derecho fundamental de participación política, constituyendo, además, la asistencia a tales actos un deber público de carácter inexcusable. Recuerda el TC los peculiares perfiles del supuesto de hecho que se plantea, pues el empresario en ningún momento impidió el cumplimiento del derecho de la recurrente al ejercicio de su participación política. La cuestión constitucional a dilucidar es determinar si, como consecuencia del ejercicio de aquel «deber público de

$41 \quad$ Véase supra p. 258. 
inexcusable cumplimiento", que ha de considerarse en su vertiente facultativa como ius in officium de la actora, por virtud de ostentar la representación política de los ciudadanos de un municipio, ha de soportar la desfavorable extinción del vínculo laboral propiciado por el despido, o, por el contrario, la decisión empresarial de despedirla, pese a la acreditada justificación de aquel absentismo laboral de la trabajadora a su cargo, ha vulnerado el derecho de esta a la participación política. Afirma el TC que el ejercicio de la función representativa supone una alteración objetiva de los términos en los que se desarrolla materialmente la relación laboral. Asimismo, destaca que el art. 52 d) LET contempla, como modalidad de extinción del contrato de trabajo por causas objetivas, las faltas de asistencia al trabajo que se produzcan de modo intermitente, aun cuando lo sean por causas justificadas y siempre que sobrepasen un determinado porcentaje de las jornadas hábiles durante los períodos de tiempo que expresamente se citan en el precepto de referencia. Además, señala que la protección que dispensa el art. 23.2 CE no puede implicar la absoluta intangibilidad de la situación profesional o laboral que el cargo electo haya tenido antes de ejercer su actividad política. Considera el TC que, si bien el ejercicio de este derecho ha de ser considerado como una causa justificada para ausentarse del puesto de trabajo, estando el empresario obligado a facilitar su legítimo ejercicio, la Constitución no ampara que los costes derivados del legítimo ejercicio de tal función representativa sean unilateralmente asumidos, más allá de lo razonable, por quien es un tercero ajeno a la relación fiduciaria entablada entre el representante político y los ciudadanos representados, en este caso por el empresario, que ha dado empleo a quien resulta elegido para ejercer un cargo público. Pues bien, considera el TC que, si bien la decisión de despido por causas objetivas, apoyada en la ausencia del puesto de trabajo de la recurrente, es apta para la satisfacción de los intereses legítimos empresariales, sin embargo, el despido acordado contraviene el contenido esencial del derecho de participación política de la actora, toda vez que constituye una medida definitiva que pone fin a la relación laboral que esta tenía con el empleador para que este último pueda ver satisfecho un objetivo empresarial que podría haber sido alcanzado con otras medidas alternativas, menos gravosas para la trabajadora, que están previstas en el ordenamiento, y que habrían podido satisfacer también aquellos intereses legítimos empresariales.

5. En la STC 93/2018 (Sala Segunda), de 17 de septiembre ${ }^{42}$, censuró el emplazamiento por edictos del que fue objeto la demandante para comunicar la iniciación de un procedimiento administrativo sancionador ha vulnerado

42 Véanse supra pp. 257 y 259-260. 
sus derechos a ser informada de la acusación y a la defensa (art. 24.2 CE), por no haber agotado el órgano administrativo los medios de averiguación de un domicilio de notificaciones alternativo tras resultar desconocida en el domicilio que figuraba en su documento nacional de identidad.

En la STC 113/2018 (Sala Segunda), de 29 de octubre ${ }^{43}$, se analiza la sentencia dictada por la Audiencia Provincial de Barcelona, confirmada por el Tribunal Supremo, que impuso al recurrente, por un delito de tráfico de sustancias estupefacientes, una pena de prisión de efectivo cumplimiento en centro penitenciario (los dos tercios de la pena de dos ańos y seis meses) y, además, la expulsión en sustitución del tercio restante de la pena de prisión. El objeto del recurso de amparo era determinar si ello supuso una vulneración del derecho a un proceso con todas las garantías (art. 24.2 CE), en relación con el principio acusatorio, y el derecho a no sufrir indefensión del demandante de amparo $^{44}$. Recuerda el TC que se ha pronunciado en el sentido de entender necesaria la audiencia previa en casos en los que procediera la sustitución de la pena de prisión por expulsión ${ }^{45}$. De la misma manera que la decisión de expulsión del territorio nacional debe ponderar las circunstancias personales del expulsado, al estar en juego una pluralidad de intereses constitucionales, en supuestos como el analizado también el órgano judicial debe ponderar a través de una evaluación individualizada si, aunque proceda la expulsión, resulta necesario tomar la decisión excepcional de hacer cumplir una parte de la pena de prisión impuesta "para asegurar la defensa del orden jurídico y restablecer la confianza en la vigencia de la norma infringida por el delito» (art. 89.1 CP). Para ello será necesario, con carácter previo a la toma de tal decisión, abrir un nuevo trámite de alegaciones en el caso de que las partes y el

43 Véase supra p. 258.

44 Dicha decisión se adoptó en aplicación de lo dispuesto en el art. 89.1 CP, que establece que «las penas de prisión de más de un año impuestas a un ciudadano extranjero serán sustituidas por su expulsión del territorio espańol. Excepcionalmente, cuando resulte necesario para asegurar la defensa del orden jurídico y restablecer la confianza en la vigencia de la norma infringida por el delito, el juez o tribunal podrá acordar la ejecución de una parte de la pena que no podrá ser superior a dos tercios de su extensión, y la sustitución del resto por la expulsión del penado del territorio espańol. En todo caso, se sustituirá el resto de la pena por la expulsión del penado del territorio español cuando aquél acceda al tercer grado o le sea concedida la libertad condicional".

45 Y ello como consecuencia del conocimiento de la cuestión de inconstitucionalidad planteada contra el art. 89.1 CP, en la redacción dada al mismo por la Ley Orgánica 5/2010, de 22 de junio, por posible vulneración de los arts. 18, 25 y 9 CE (ATC 180/2015, FJ 4). 
Ministerio Fiscal solo se hubieran pronunciado acerca de la medida de expulsión obligatoria para penas superiores de un año de prisión. De esta manera posibilita que el acusado pueda ejercer su derecho constitucional de defensa sobre la concreta forma de cumplimiento de la pena que se le va a imponer, pudiendo alegar acerca de cualquier circunstancia que estime conveniente. En este caso, el hecho de que el acusado fuera reincidente y según la hoja del histórico penal tuviera varios antecedentes penales previos, entre ellos del delito contra la salud pública, fue lo que llevó a la Audiencia Provincial a considerar que era aconsejable aplicar lo dispuesto en el art. 89.1 CP, con el fin de restablecer la confianza en la vigencia de la norma infringida por delito cometido. No comparte el TC el razonamiento esgrimido por la Audiencia Provincial según el cual «el art. 89.1 CP de forma imperativa exige que el último tercio de la pena necesariamente deba ser sustituida», pues de lo que se trata, en última instancia, es de determinar si el recurrente debió contar con la oportunidad de defenderse de la posible aplicación excepcional de la medida sustitutiva parcial de la pena de prisión, cuando esta no estuvo presente en el debate. La Audiencia Provincial debió, por tanto, dar audiencia a las partes dentro del propio Plenario para que se pronunciaran sobre la posibilidad de aplicar la excepción a la regla obligatoria de sustitución total de cualquier pena de prisión superior a un año por la expulsión del territorio nacional. Al no proceder así, su falta supuso, de hecho, una vulneración del derecho de defensa y, por ende, a un proceso con todas las garantías.

6. En la STC 89/2018 (Pleno), de 6 de septiembre, el demandante de amparo, trabajador y miembro del comité de empresa de la mercantil Seguridad Integral Canaria, S. A., fue despedido disciplinariamente por infracción de la buena fe contractual, falsedad, deslealtad y por ofensas verbales al empresario por haber asistido a un pleno del Ayuntamiento de Las Palmas de Gran Canaria vistiendo una camiseta con el lema «donde hay corrupto hay un corruptor. Tanto o más importante que el nombre del político corrupto, es conocer el de la empresa de seguridad corruptora» y portando una careta. La demanda de amparo se dirigía contra la sentencia Tribunal Superior de Justicia que declaró la procedencia del despido disciplinario del recurrente, revocando la calificación de improcedencia declarada por la sentencia de instancia; a juicio del recurrente, la resolución judicial impugnada lesionó los derechos fundamentales de libertad de expresión (art. 20.1a CE) y de libertad sindical (art. 28.1 CE). Explica el TC que en el presente caso se plantea la cuestión relativa a la protección del derecho fundamental a la libertad de expresión frente al ejercicio del poder disciplinario empresarial en el seno de una relación de trabajo, si bien con los dos matices: el sancionado es representante 
de los trabajadores y, además, la protesta se dirigía frente a los representantes públicos, cuya pasividad, ante una situación de conflictividad laboral en la contrata de vigilancia y seguridad del ayuntamiento, se cuestionaba. Recuerda el TC que la celebración de un contrato de trabajo no implica, en modo alguno, la privación para una de las partes, el trabajador, de los derechos que la Constitución le reconoce como ciudadano. De este modo, el TC ha venido reiterando que la legítima actuación en el seno de la empresa, para defender los intereses a cuyo fin se articulan las representaciones de los trabajadores, necesita de garantías frente a todo acto de injerencia, impeditivo u obstaculizador del ejercicio de esa libertad, entre ellas, figura la de la indemnidad, esto es, el derecho del trabajador a no sufrir, por razón de su afiliación o actividad sindical, menoscabo alguno en su situación profesional o económica en la empresa. Examina el TC si el recurrente hizo un uso legítimo de su derecho fundamental a la libertad sindical cuando, en virtud de lo acordado en una reunión del sindicato Intersindical Canaria, junto con otros miembros del comité de empresa de la mercantil Seguridad Integral Canaria, S. A., en el contexto de un clima de conflictividad laboral derivado de la queja por incumplimiento de los derechos laborales en materia salarial, en el curso de una sesión del pleno del Ayuntamiento de Las Palmas de Gran Canaria, se levantó del asiento que ocupaba poniéndose una careta con la imagen de un controvertido personaje público, y exhibiendo una camiseta en cuyo anverso se podía leer el lema: «donde hay corrupto hay un corruptor. Tanto o más importante que el nombre del político corrupto, es conocer el de la empresa de seguridad corruptora», constando junto al mensaje escrito una imagen impresa en la que se apreciaban dos personas que estaban entregándose dinero. Para ponderar tal actuación, el TC toma en consideración que los representantes de los trabajadores, además de cuestionar la conducta del empleador, criticaban la gestión llevada a cabo por el Ayuntamiento, que, pese a adjudicar la prestación del servicio en materia de seguridad individual y colectiva a la referida empresa, habría consentido en el impago de los salarios fijados en el convenio colectivo a los trabajadores de la contrata. La sentencia recurrida entendió que la conducta del demandante traspasó los límites que impone el respeto al derecho al honor de los responsables de la empresa y de la Administración receptora del servicio, ya que el ejercicio de la libertad de expresión no puede justificar el empleo de expresiones o apelativos insultantes, injuriosos o vejatorios. No comparte tal argumentación el TC, que considera que los órganos judiciales han omitido en su ponderación la condición del demandante; el contenido del mensaje; la necesidad y finalidad del mismo; la proyección o notoriedad pública de los destinatarios a los que iba dirigido; el modo en que quedó en su caso afectado su honor o su prestigio profesional o empresarial; 
la forma, medio o lugar en que se proyectó; su difusión y el grado de conexión con actividades de interés público, y el daño sufrido por la empresa, así como el contexto en que se realizaron. Resalta el TC que el demandante actuaba como miembro del comité de empresa junto con otros representantes de los trabajadores en la defensa y protección de los derechos e intereses de estos, es decir, no se trataba de un trabajador más; por otra parte, destaca el lugar y los destinatarios de la protesta, así como el medio, la forma utilizada para formularla, el posible daño sufrido por la empresa o el ambiente en el que se realizaron, elementos estos, que tampoco han sido adecuadamente considerados en la sentencia impugnada. Es importante en opinión del TC tomar en consideración que los hechos que dan lugar al despido disciplinario acontecen durante un pleno del Ayuntamiento de Las Palmas de Gran Canaria. Recuerda además que los límites permisibles de la crítica son más amplios si esta se refiere a personas que se dedican a actividades públicas; además, ponderando las circunstancias concurrentes, toma en consideración que el demandante no identificó claramente en el mensaje como "político corrupto» a ningún miembro del Ayuntamiento, tampoco utilizó la denominación de la empleadora al aludir a la «empresa de seguridad corruptora», ni señaló en el mensaje a cualquier responsable de la misma. La indeterminación de la «empresa de seguridad corruptora» dificultó que la misma fuera identificada por aquellos que no tuvieran implicación alguna en el conflicto. Por ello, no comparte la afirmación de la sentencia impugnada cuando indica que la actuación alcanzó al honor de los responsables de la empresa, pues estos no aparecen en modo alguno determinados. Por último destaca que la protesta se realizó sin altercado alguno y sin que tan siquiera conste que el pleno del Ayuntamiento sufriera interrupción. Por ello considera que debe otorgarse el amparo solicitado. En igual sentido, las SSTC 108 y 109/2018 (Sala Primera), de 15 de octubre; las SSTC 114, 115, 116/2018 (Sala Primera), de 29 de octubre, y 118/2018 (Sala Segunda), de 29 de octubre.

En la STC 123/2018 (Sala Primera), de 12 de noviembre ${ }^{46}$, el problema era determinar si se había vulnerado el derecho a la libertad sindical (art. 28.1 CE) del recurrente, al descartarse por la sentencia impugnada la aplicación de la "garantía de prioridad de permanencia en la empresa» reconocida legalmente a los representantes de los trabajadores en caso de despido objetivo, y cuyo alcance temporal se extendía por el convenio colectivo aplicable «hasta tres años después del cese en el cargo» representativo. Aunque en el caso no se habían superado esos tres años a los que hace mención la norma convencional, la sentencia impugnada negó al recurrente el derecho a la prioridad de

$46 \quad$ Véase supra p. 257. 
permanencia en la empresa por haber cesado como delegado sindical antes del despido, por entender que la regulación legal aplicable no reconoce la extensión de la garantía a un momento posterior al cese. Recuerda el TC que el art. 28.1 CE integra, además de la vertiente organizativa de la libertad sindical, los derechos de actividad y medios de acción de los sindicatos — huelga, negociación colectiva, promoción de conflictos-, que constituyen el núcleo mínimo, indispensable e indisponible de la libertad sindical. Junto con aquellos, los sindicatos pueden ostentar también derechos o facultades adicionales atribuidos por normas legales o convenios colectivos que pasan a engrosar o a ańadirse a aquel núcleo esencial. De este modo, el derecho fundamental de libertad sindical no solo se integra por su «contenido esencial» mínimo indispensable, sino también por el referido "contenido adicional». Tales facultades, en la medida que sobrepasan el contenido esencial y son de creación «infraconstitucional», deben ser ejercitadas en el marco de su regulación, pudiendo ser alteradas o suprimidas por las normas que las establecen, no estando su configuración sometida a más límite que el de no vulnerar el contenido esencial del derecho de libertad sindical. Dentro de ese "contenido adicional» se enmarca «la facultad de que el delegado sindical pueda desarrollar las funciones y gozar de las garantías legalmente reconocidas». Una de esas garantías es precisamente la "prioridad de permanencia en la empresa o centro de trabajo» del representante sindical en caso de despido por causas económicas, que supone una limitación de los poderes empresariales de dirección y organización en lo relativo a la selección de los trabajadores que pueden resultar afectados por la indicada decisión extintiva. Analiza el TC si la sentencia impugnada vulneró el derecho de libertad sindical del recurrente, por haber confirmado, revocando la sentencia de instancia, la decisión empresarial que le deniega la "garantía de prioridad de permanencia en la empresa" en los términos establecidos en la normativa de aplicación. Concluye el TC que el Tribunal Superior de Justicia privó al demandante de la «garantía de prioridad de permanencia en la empresa» mediante un razonamiento que prescinde absolutamente de la regulación contenida en el convenio colectivo y obvia así su fuerza vinculante (art. 37.1 CE), así como el papel que desempeña la negociación colectiva como «instrumento esencial para la ordenación de las relaciones de trabajo ${ }^{47}$ \%.

47 Carlos Ortega Carballo. 